\title{
Observation of atmospheric aerosols at Mt. Hua and Mt. Tai in central and east China during spring 2009 - Part 1: EC, OC and inorganic ions
}

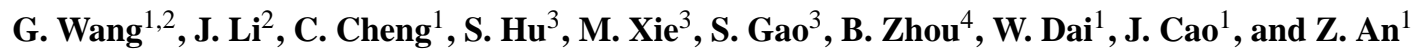 \\ ${ }^{1}$ State Key Laboratory of Loess and Quaternary Geology, Institute of Earth Environment, Chinese Academy of Sciences, \\ Xi'an 710075, China \\ ${ }^{2}$ Department of Environmental Science and Engineering, Xi' an Jiaotong University, Xi' an 710049, China \\ ${ }^{3}$ School of the Environment, State Key Laboratory of Pollution Control and Resources Reuse, Nanjing University, \\ Nanjing 210093, China \\ ${ }^{4}$ Department of Geographical Science and Environment Engineering, Baoji University of Art and Science, \\ Baoji 721013, China
}

Received: 2 January 2011 - Published in Atmos. Chem. Phys. Discuss.: 24 January 2011

Revised: 13 April 2011 - Accepted: 27 April 2011 - Published: 6 May 2011

\begin{abstract}
PM}_{10}$ and size-segregated samples were simultaneously collected at Mt. Hua (2060 ma.s.l.) and Mt. Tai (1545 ma.s.l.) in central and east coastal China during spring, 2009 including an intensive dust storm event occurring on 24 April, and determined for EC, OC and inorganic ions. During the non-dust storm period particles, EC, OC and ions except for $\mathrm{SO}_{4}^{2-}$ were 2-10 times more abundant at Mt. Tai than at Mt. Hua. $\mathrm{SO}_{4}^{2-}\left(13 \pm 7.1 \mu \mathrm{g} \mathrm{m}^{-3}\right)$ at Mt. Hua was the dominant ion, followed by $\mathrm{NO}_{3}^{-}\left(5.0 \pm 3.9 \mu \mathrm{g} \mathrm{m}^{-3}\right), \mathrm{NH}_{4}^{+}$ $\left(2.5 \pm 1.3 \mu \mathrm{g} \mathrm{m}^{-3}\right)$ and $\mathrm{Ca}^{2+}\left(1.6 \pm 0.8 \mu \mathrm{g} \mathrm{m}^{-3}\right)$. In contrast, at Mt. Tai $\mathrm{NO}_{3}^{-}$was most abundant $\left(20 \pm 14 \mu \mathrm{g} \mathrm{m}^{-3}\right)$, followed by $\mathrm{SO}_{4}^{2-}\left(16 \pm 13 \mu \mathrm{g} \mathrm{m}^{-3}\right), \mathrm{NH}_{4}^{+}\left(12 \pm 8.9 \mu \mathrm{g} \mathrm{m}^{-3}\right)$ and $\mathrm{Ca}^{2+}\left(3.9 \pm 2.1 \mu \mathrm{g} \mathrm{m}^{-3}\right)$. The fact of $\mathrm{NO}_{3}^{-}$exceeding over $\mathrm{SO}_{4}^{2-}$ at Mt. Tai may suggest the changes in chemical composition of the atmosphere over east China due to sharply increasing vehicle emission. $\mathrm{pH}$ values of the water-extracts of $\mathrm{PM}_{10}$ samples indicate that at the two mountain sites aerosols transported from the south regions are more acidic than those from the north and more acidic at Mt. Tai than at Mt. Hua during the non-dust storm period. During the dust storm event particle mass, $\mathrm{OC}, \mathrm{Na}^{+}, \mathrm{K}^{+}, \mathrm{Mg}^{2+}$ and $\mathrm{Ca}^{2+}$ at both sites increased by a factor of $1-9$, while $\mathrm{EC}, \mathrm{NO}_{3}^{-}$and $\mathrm{NH}_{4}^{+}$decreased by $20-80 \%$. However, $\mathrm{SO}_{4}^{2-}$ concentrations $\left(13 \pm 7.7 \mu \mathrm{g} \mathrm{m}^{-3}\right.$ at Mt. Hua and $15 \pm 5.6 \mu \mathrm{g} \mathrm{m}^{-3}$ at Mt. Tai, respectively) at the two sites during the episode were compa-
\end{abstract}

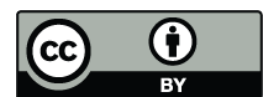

Correspondence to: $\mathrm{G}$. Wang

(wanggh@ieecas.cn) rable and did not change significantly compared to those in the non-dust storm period, probably due to a similar level of free tropospheric $\mathrm{SO}_{2}$ in central and east China.

Compared with those at Mt. Hua the coarse modes $(>2.1 \mu \mathrm{m})$ of $\mathrm{K}^{+}$and $\mathrm{SO}_{4}^{2-}$ at Mt. Tai during the non-event period were more abundant and the coarse mode of $\mathrm{NO}_{3}^{-}$was less abundant. When the dust storm was present all ions significantly moved toward coarse particles, except for $\mathrm{NH}_{4}^{+}$, with a disappeared peak in fine mode $(<2.1 \mu \mathrm{m})$ for $\mathrm{NO}_{3}^{-}$. Linear regression for ion equivalents in fine particles indicates that ammonium exists in the forms of $\mathrm{NH}_{4} \mathrm{NO}_{3}$ and $\mathrm{NH}_{4} \mathrm{HSO}_{4}$ at Mt. Hua and $\mathrm{NH}_{4} \mathrm{NO}_{3}$ and $\left(\mathrm{NH}_{4}\right)_{2} \mathrm{SO}_{4}$ at Mt. Tai during both the nonevent and the event periods. While the regression for coarse mode of $\mathrm{Ca}^{2+}$ suggests a close coupling of dust with nitrate during the nonevent time and with sulfate during the dust-storm period. $\mathrm{pH}$ values of the sizeresolved samples further suggest that during the nonevent period most acidic particles at Mt. Hua are in the range of 0.7$1.1 \mu \mathrm{m}$, while those at Mt. Tai are in the range of 1.1-2.1 $\mu \mathrm{m}$. Aerosols at both sites became alkaline during the event, but the Mt. Tai particles still showed a lower $\mathrm{pH}$ value.

\section{Introduction}

Asian dust storms, which often occur in spring, are lofted up by strong winds from central Asia and Gobi deserts and can be transported into East Asia, North America (Arimoto et al., 2006; Heald et al., 2006; Leaitch et al., 2009;

Published by Copernicus Publications on behalf of the European Geosciences Union. 


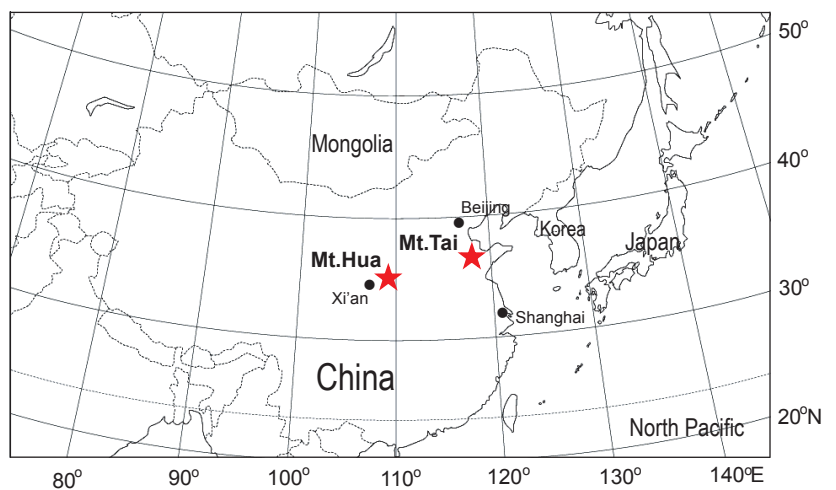

Fig. 1. Sampling sites of Mt. Hua and Mt. Tai in East Asia.

Parrington et al., 1983; VanCuren and Cahill, 2002; Wilkening et al., 2000), and even be transported more than one full circuit around the globe within two weeks (Uno et al., 2009). During the long-range transport, dust particles react with a diversity of chemical species, coagulate with other particles, and/or provide reaction sites in the atmosphere, exerting a significant impact on the atmospheric environment (Huebert et al., 2003; Sun et al., 2010; Tobo et al., 2010; Trochkine et al., 2003) and human health (Chiu et al., 2008; Hong et al., 2010; Singh et al., 2009) of the downwind regions.

Numerous studies on changes in the chemical properties of Asian dust particles during long-range transport have been documented (Kanayama et al., 2002; Parrington et al., 1983; Zhang et al., 2003), but most of them were performed in urban (Huang et al., 2010b; Sun et al., 2004; Wang et al., 2002b, 2003; Yuan et al., 2008; Zhang et al., 2009), rural and marine areas (Decesari et al., 2005; Geng et al., 2009; Kanayama et al., 2002; Wang et al., 2009a) . In contrast, only a limited number of observations on aerosol chemistry were conducted at alpine sites, most of which are situated in the eastern part of China (Gao et al., 2005; Wang et al., 2009b, 2009c). Atmospheric environment in mountain area is unique because of lower temperature, higher relative humidity (RH), and stronger solar radiation. Tropospheric aerosols over mountain areas are derived mostly from longrange transport, and are thus representative of atmospheric characters in a larger scale. Recently Rosenfeld et al. (2007) found that the decreasing precipitation in mountain area of inland China is deeply linked with the increasing air pollution. Satellite observations (Richter et al., 2005; van Donkelaar et al., 2010) also pointed out that $\mathrm{NO}_{2}$ and particle levels in east China are the highest in the world. These increasing anthropogenic pollutants, together with the frequent occurrence of dust storm, may have been changing the physiochemical properties of the downwind atmosphere (Huebert et al., 2003; IPCC, 2007; Liu and Diamond, 2005; Mori et al., 2003; Seinfeld et al., 2004).
Table 1. Meteorological parameters during the sampling period.

\begin{tabular}{lccc}
\hline & $T^{\mathrm{a}},{ }^{\circ} \mathrm{C}$ & $\mathrm{RH}^{\mathrm{b}}, \%$ & $V^{\mathrm{c}}, \mathrm{km}$ \\
Mt. Hua & $5.8 \pm 5.5$ & $58 \pm 21$ & $15 \pm 4.6$ \\
Mt. Tai & $4.9 \pm 5.2$ & $63 \pm 20$ & $16 \pm 9.2$ \\
\hline
\end{tabular}

${ }^{\mathrm{a}}$ Temperature, ${ }^{\mathrm{b}}$ relative humidity, ${ }^{\mathrm{c}}$ visibility.

The purpose of this study is to recognize the difference in composition, concentration and size distribution of inorganic ions and elemental and organic carbon in airborne particles between Mt. Hua and Mt. Tai, two mountains located in central and east China, and investigate the impact of dust storm on aerosol chemistry of the mountain atmospheres.

\section{Experimental section}

\subsection{Sample collection}

Sampling sites of Mt. Hua $\left(34.48^{\circ} \mathrm{N}, 110.08^{\circ} \mathrm{E}, 2060\right.$ $\mathrm{m}$ a.s.l.) and Mt. Tai $\left(36.27^{\circ} \mathrm{N}, 117.10^{\circ} \mathrm{E}, 1545 \mathrm{~m}\right.$ a.s.l.) are situated in mid and east China, respectively (Fig. 1). TSP and $\mathrm{PM}_{10}$ samples were collected in a 24-h interval at an airflow rate of $1001 \mathrm{~min}^{-1}$ by using two mid-volume samplers (KC$120 \mathrm{H}$, Qingdao Laoshan Company, China) fixed on a rooftop of the Meteorological Observation Station at the summits of Mt. Hua and Mt. Tai. Size-segregated particles were simultaneously collected at the same sites using a 9-stage sampler (Andersen, USA) at an airflow rate of $28.31 \mathrm{~min}^{-1}$ with cutoff points as 0.4, 0.7, 1.1, 2.1, 3.3, 4.7, 5.8, and $9.0 \mu \mathrm{m}$. Each set of the size-segregated samples was continuously collected for 4-6 days depending on aerosol loading. All the samples were collected onto pre-combusted $\left(450^{\circ} \mathrm{C}, 6 \mathrm{~h}\right)$ quartz filters and the air inlets were around $5-10 \mathrm{~m}$ above the ground. The Mt. Hua sampling was performed from 25 March to 29 April 2009, while the sampling at Mt. Tai was conducted from 27 March to 29 April 2009. On 24 April a massive dust storm originating from Gobi desert arrived in Mt. Hua and Mt. Tai simultaneously, during which TSP and $\mathrm{PM}_{10}$ sampling time was changed into 3-6h. Sampling at Mt. Tai for size-segregated particles was stopped during the event due to instrument problem of the 9-stage sampler, thus the sizeresolved data for the dust storm period are unavailable. Field blank was collected before and after the sampling by mounting a filter onto the sampler for about 10 min without sucking any air. After sampling, the sample and the blank filters were sealed in an aluminum foil, transported into the lab and stored in a freezer under $-20^{\circ} \mathrm{C}$ prior to analysis. Meteorological parameters at the two sites during the sampling periods are given in Table 1. 


\subsection{Sample analysis}

\subsubsection{Inorganic ions}

Detailed analytical method for inorganic ions has been reported elsewhere (Wang et al., 2002a, 2010). Here we only give a brief introduction. Filter aliquots from $\mathrm{PM}_{10}$ and the size-segregated samples were cut in pieces and extracted with $5 \mathrm{ml}$ pure water for 3 times each in $10 \mathrm{~min}$ by ultrasonication, respectively. Then the combined water-extracts were filtered through a PTFE filter to remove the particles and filter debris, and determined for $\mathrm{pH}$ using a $\mathrm{pH}$ meter (HANNA HI8424 $\mathrm{pH}$ meter, US) at an ambient temperature of $25^{\circ} \mathrm{C}$ and inorganic ions using an ion chromatograph (Dionex 500, Dionex, US). Particle mass on the filter was gravimetrically measured using an electronic balance (Sartorius E5, Germany) under a relative humidity of $40 \pm 5 \%$ at ambient temperature.

\subsubsection{Organic carbon (OC) and elemental Carbon (EC)}

OC and EC in the TSP and $\mathrm{PM}_{10}$ samples were analyzed using DRI Model 2001 Carbon Analyzer following the Interagency Monitoring of Protected Visual Environments (IMPROVE) thermal/optical reflectance (TOR) protocol (Chow et al., 2004, 2007). Briefly, a size of $0.526 \mathrm{~cm}^{2}$ sample filter was put in a quartz boat inside the analyzer and progressively heated to temperatures of $120^{\circ}, 250^{\circ}, 450^{\circ}$, and $550^{\circ}$ in a non-oxidizing helium (He) atmosphere, and $550^{\circ}, 700^{\circ}$, and $800^{\circ}$ in an oxidizing atmosphere of $2 \%$ oxygen in helium.

Inorganic ions, EC and OC in the field blanks were less than $10 \%$ of those in real samples. Data reported here were all subtracted by the blanks. An intercomparison was made by comparing the species determined in $\mathrm{PM}_{10}$ with those in the corresponding size-segregated samples. A good linear correlation was obtained for the two data sets (Fig. 2), demonstrating the consistency between the two samplers.

\section{Results and discussion}

\subsection{Chemical compositions}

\subsubsection{General description}

Figure 3 shows the temporal variations of TSP and $\mathrm{PM}_{10}$ during the campaign, while concentrations of chemical species in the samples are presented in Table 2. TSP and $\mathrm{PM}_{10}$ during the non-dust storm periods were $103 \pm 42$ and $71 \pm$ $28 \mu \mathrm{g} \mathrm{m}^{-3}$ at Mt. Hua, accounting for about $50 \%$ of those at Mt. Tai. The massive dust storm event on 24 April significantly affected the atmospheres over both mountains with the highest 3-h TSP and $\mathrm{PM}_{10}$ concentrations being 991 and $740 \mu \mathrm{g} \mathrm{m}^{-3}$ at Mt. Hua and 2280 and $1797 \mu \mathrm{g} \mathrm{m}^{-3}$ at Mt. Tai (Fig. 3), 6-8 times more abundant than those in the nonevent time. Although the lower altitude of Mt. Tai is more accessible to pollutants from lowland sources, the higher levels

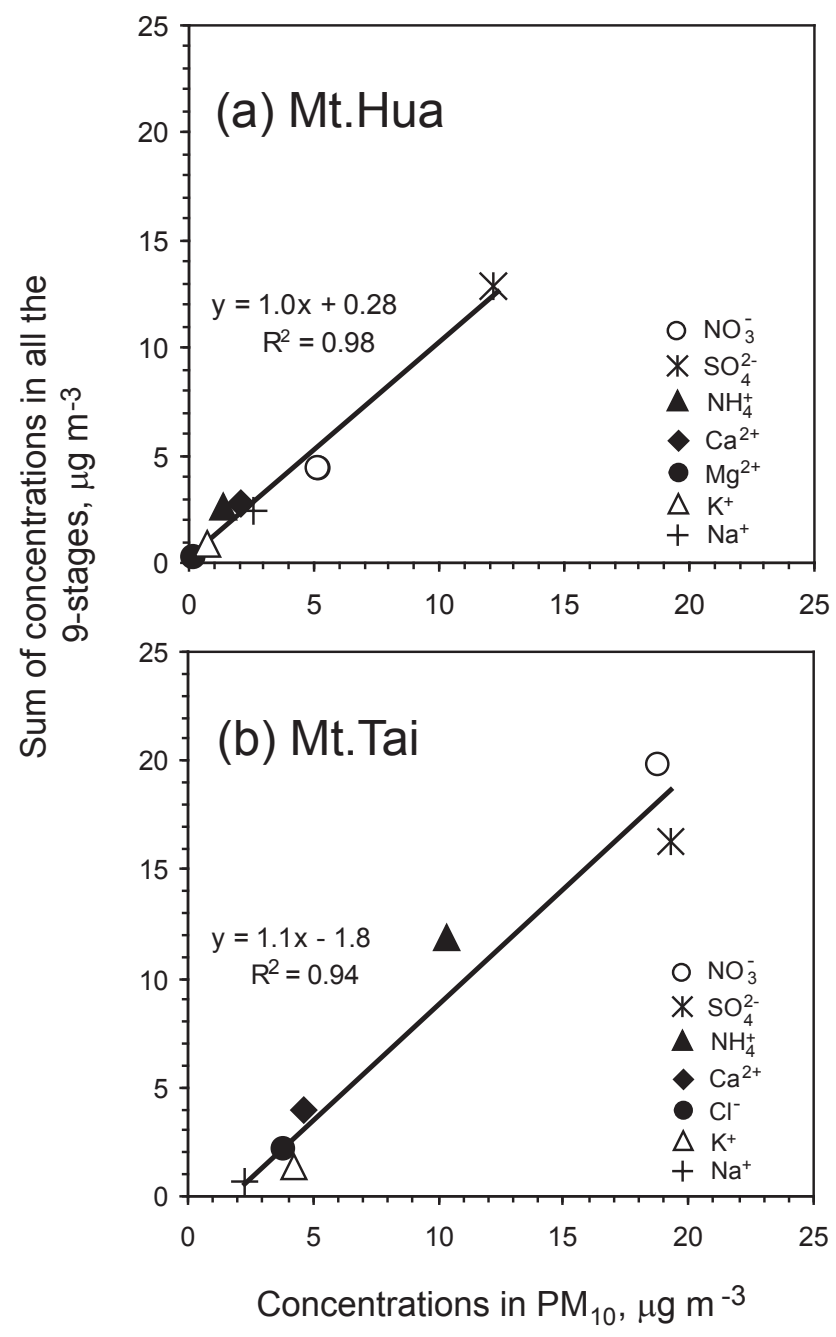

Fig. 2. An intercomparison of major components measured by the $\mathrm{PM}_{10}$ and 9-stage samplers.

of TSP and $\mathrm{PM}_{10}$ at Mt. Tai in both the nonevent and event periods clearly demonstrate that aerosol pollution at Mt. Tai is more serious than at Mt. Hua, which is consistent with results observed by satellite and aircraft measurements for $\mathrm{NO}_{2}$ (Richter et al., 2005) and $\mathrm{PM}_{2.5}$ (van Donkelaar et al., 2010).

\subsubsection{Non-dust storm period}

As shown in Fig. 4 and Table 2, concentrations of $\mathrm{SO}_{4}^{2-}$ and $\mathrm{Na}^{+}$of $\mathrm{PM}_{10}$ during the non-dust storm period in the Mt. Tai atmosphere are comparable to those in the air of Mt. Hua, but $\mathrm{PM}_{10}$, EC, OC and other ions at Mt. Tai are 210 times more abundant than those at Mt. Hua especially for $\mathrm{Cl}^{-}, \mathrm{NO}_{3}^{-}, \mathrm{NH}_{4}^{+}$, and $\mathrm{K}^{+}$. Potassium ion has been considered a key tracer for biomass burning emissions (Engling and Gelencser, 2010; Li et al., 2003). Several studies on vegetation fire emissions from Africa savanna found that the smoke was enriched in $\mathrm{Cl}^{-}$, and almost the entire amount released 
Table 2. Concentrations of OC, EC and inorganic ions in aerosols from the atmospheres of Mt. Hua and Mt. Tai in China during the spring of $2009, \mu \mathrm{g} \mathrm{m}^{-3}$.

\begin{tabular}{|c|c|c|c|c|c|}
\hline & \multicolumn{3}{|c|}{ Mt. Hua } & \multicolumn{2}{|c|}{ Mt. Tai } \\
\hline & $\begin{array}{l}\text { Non-dust storm } \\
\qquad(\mathrm{n}=31)\end{array}$ & $\begin{array}{r}\text { Dust storm I } \\
\qquad(\mathrm{n}=1)\end{array}$ & $\begin{array}{r}\text { Dust storm II } \\
\qquad(\mathrm{n}=2)\end{array}$ & $\begin{array}{r}\text { Non-dust storm } \\
\qquad(\mathrm{n}=29)\end{array}$ & $\begin{array}{r}\text { Dust storm II } \\
\qquad(\mathrm{n}=3)\end{array}$ \\
\hline \multicolumn{6}{|c|}{ Total suspended particles (TSP) } \\
\hline $\mathrm{PM}^{\mathrm{a}}$ & $103 \pm 42$ & 365 & $689 \pm 355$ & $205 \pm 77$ & $1759 \pm 542$ \\
\hline $\mathrm{OC}$ & $5.9 \pm 1.6$ & 15 & $28 \pm 12$ & $13 \pm 5.8$ & $49 \pm 12$ \\
\hline $\mathrm{EC}$ & $1.4 \pm 0.5$ & 1.4 & $0.6 \pm 0.7$ & $3.3 \pm 1.9$ & $\mathrm{Nd}^{\mathrm{b}}$ \\
\hline \multicolumn{6}{|c|}{ Particles in diameter less than $10 \mu \mathrm{m}\left(\mathrm{PM}_{10}\right)$} \\
\hline $\mathrm{PM}^{\mathrm{a}}$ & $71 \pm 28$ & 173 & $506 \pm 303$ & $159 \pm 60$ & $1343 \pm 450$ \\
\hline OC & $4.9 \pm 1.4$ & 8 & $23 \pm 11$ & $13 \pm 5.9$ & $40 \pm 14$ \\
\hline $\mathrm{EC}$ & $1.2 \pm 0.5$ & 1.0 & $0.6 \pm 0.6$ & $2.8 \pm 2.1$ & $\mathrm{Nd}^{\mathrm{b}}$ \\
\hline $\mathrm{pH}^{\mathrm{c}}$ & $-0.0 \pm 0.6$ & 0.9 & $0.8 \pm 0.2$ & $-1.2 \pm 0.7$ & $0.2 \pm 0.0$ \\
\hline $\mathrm{F}^{-}$ & $0.1 \pm 0.1$ & 0.1 & $0.0 \pm 0.1$ & $0.1 \pm 0.1$ & $0.3 \pm 0.1$ \\
\hline $\mathrm{Cl}^{-}$ & $0.2 \pm 0.2$ & 0.7 & $0.8 \pm 0.8$ & $2.2 \pm 1.7$ & $1.9 \pm 0.7$ \\
\hline $\mathrm{NO}_{3}^{-}$ & $5.0 \pm 3.9$ & 4.1 & $3.9 \pm 1.5$ & $20 \pm 14$ & $13 \pm 3.1$ \\
\hline $\mathrm{SO}_{4}^{2-}$ & $13 \pm 7.1$ & 6.1 & $13 \pm 7.7$ & $16 \pm 13$ & $15 \pm 5.6$ \\
\hline $\mathrm{Na}^{+}$ & $0.7 \pm 0.8$ & 2.4 & $5.7 \pm 2.3$ & $0.7 \pm 0.4$ & $3.2 \pm 1.2$ \\
\hline $\mathrm{NH}_{4}^{+}$ & $2.5 \pm 1.3$ & 1.0 & $1.2 \pm 0.2$ & $12 \pm 8.9$ & $4.2 \pm 1.5$ \\
\hline $\mathrm{K}^{+}{ }^{4}$ & $0.3 \pm 0.2$ & 0.3 & $0.5 \pm 0.3$ & $1.3 \pm 0.8$ & $1.8 \pm 0.7$ \\
\hline $\mathrm{Mg}^{2+}$ & $0.1 \pm 0.1$ & 0.3 & $0.4 \pm 0.2$ & $0.4 \pm 0.4$ & $1.1 \pm 0.3$ \\
\hline $\mathrm{Ca}^{2+}$ & $1.6 \pm 0.8$ & 2.0 & $4.7 \pm 2.0$ & $3.9 \pm 2.1$ & $25 \pm 7.0$ \\
\hline Total ions & $23 \pm 11$ & 17 & $30 \pm 12$ & $57 \pm 39$ & $64 \pm 19$ \\
\hline
\end{tabular}

${ }^{\mathrm{a}} \mathrm{PM}$ : particle mass; ${ }^{\mathrm{b}} \mathrm{Nd}$ : not detected; ${ }^{\mathrm{c}} \mathrm{pH}=\mathrm{pH}$ of water-extracts of the samples $-\mathrm{pH}$ of water-extracts of the filed blanks.

during the fires was present in particle phase (Andreae et al., 1998; Pósfai et al., 2003). Thus, a strong linear correlation $\left(r^{2}=0.79\right.$, Fig. $5 b$ ) found between $\mathrm{Cl}^{-}$and $\mathrm{K}^{+}$for the nondust $\mathrm{PM}_{10}$ samples indicates that the high levels of $\mathrm{Cl}^{-}$and $\mathrm{K}^{+}$at Mt. Tai were mostly derived from biomass burning emissions in the North China Plain (NCP). However, such a significant correlation was not observed for the related samples at Mt. Hua (Fig. 5a). The equivalent ratio of $\mathrm{Cl}^{-} / \mathrm{K}^{+}$ during the non-dust storm period was $0.5 \pm 0.8$ and $1.7 \pm 0.7$ at Mt. Hua and Mt. Tai, respectively, suggesting that $\mathrm{KCl}$ salt is not the only form by which $\mathrm{Cl}^{-}$and $\mathrm{K}^{+}$exist in the samples, and they may have other origins or experienced additional atmospheric processes during the transport of biomass burning smoke such as deposition and/or reaction with acidic gases. Chinese loess and dust from Gobi desert also contain certain amount of $\mathrm{Cl}^{-}$and $\mathrm{K}^{+}$(Cao et al., 2008). Arimoto et al. (2004) reported that springtime TSP aerosols at Zhenbeitai, a site located in inland China, contain some amount of $\mathrm{Cl}^{-}\left(0.5 \pm 0.5 \mu \mathrm{g} \mathrm{m}^{-3}\right)$ and $\mathrm{K}^{+}\left(0.3 \pm 0.2 \mu \mathrm{g} \mathrm{m}^{-3}\right)$ during non-dust storm periods. Size distribution of particles at both mountain sites showed that a significant amount of $\mathrm{Cl}^{-}$and $\mathrm{K}^{+}$was enriched in particles with a diameter larger than $3 \mu \mathrm{m}$, especially when dust was present (see detailed discussion in Sect. 3.2), indicating an important contribution of soil/dust to the particulate $\mathrm{Cl}^{-}$and $\mathrm{K}^{+}$in the mountain atmospheres in addition to the contributions from biomass burning, dried salt lakes and sea salt, which results in the equivalent ratio of $\mathrm{Cl}^{-}$and $\mathrm{K}^{+}$being different from unity. Recent studies on biomass burning events have reported that $\mathrm{KCl}$ salt abundantly existing in young smoke can readily be converted into $\mathrm{K}_{2} \mathrm{SO}_{4}$ and $\mathrm{KNO}_{3}$ during the smoke aging process by reacting with acid gases $\mathrm{HNO}_{3}$ and $\mathrm{H}_{2} \mathrm{SO}_{4}$ (Hand et al., 2005; Ikegami et al., 2001; Li et al., 2003; Pósfai et al., 2003). $\mathrm{HNO}_{3}$ and $\mathrm{N}_{2} \mathrm{O}_{5}$ have been confirmed to be of ability to react with $\mathrm{NaCl}$ and release $\mathrm{HCl}$, latter may further react with atmospheric alkaline particles like $\mathrm{CaCO}_{3}$ (Finlayson-Pitts et al., 1989; Tobo et al., 2010). High levels of $\mathrm{HNO}_{3}$ and $\mathrm{N}_{2} \mathrm{O}_{5}$ in mega-cities in east coastal China have been documented recently (Pathak et al., 2009, 2010; Wang et al., 2011), thus it is possible that $\mathrm{KCl}$ salt in the atmosphere of Mt. Tai may react with $\mathrm{HNO}_{3}$ and $\mathrm{N}_{2} \mathrm{O}_{5}$ in the same manner as does $\mathrm{NaCl}$, which is another factor leading to the equivalent ratio of particulate $\mathrm{Cl}^{-}$and $\mathrm{K}^{+}$not be unity.

The high concentrations of $\mathrm{NO}_{3}^{-}$and $\mathrm{NH}_{4}^{+}$at Mt. Tai are caused by high emissions of $\mathrm{NO}_{\mathrm{x}}$ and $\mathrm{NH}_{3}$ because of the sharp increase in vehicle numbers and the more active agricultural practice in NCP. Atmospheric aerosols at Mt. Hua during the normal days, i.e., the non-dust storm period, 


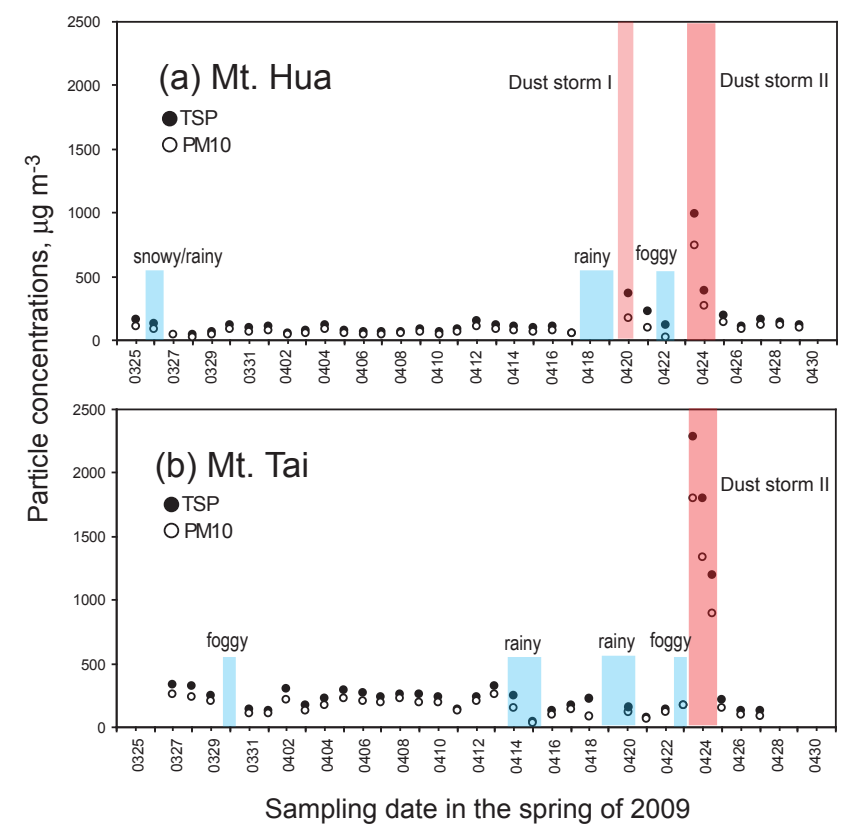

Fig. 3. Temporal variations of TSP and $\mathrm{PM}_{10}$ concentrations in the atmospheres over Mt. Hua and Mt. Tai during spring 2009.

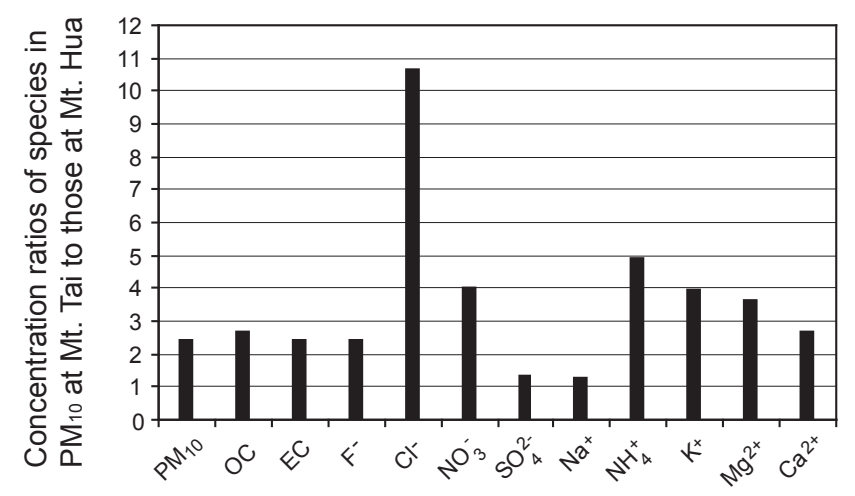

Fig. 4. Difference in the concentrations of species in $\mathrm{PM}_{10}$ between Mt. Hua and Mt. Tai during the non-dust storm period in spring 2009.

were dominated by $\mathrm{SO}_{4}^{2-}\left(13 \pm 7.1 \mu \mathrm{g} \mathrm{m}^{-3}\right.$, Table 2$)$, followed by $\mathrm{NO}_{3}^{-}\left(5.0 \pm 3.9 \mu \mathrm{g} \mathrm{m}^{-3}\right), \mathrm{NH}_{4}^{+}\left(2.5 \pm 1.3 \mu \mathrm{g} \mathrm{m}^{-3}\right)$, $\mathrm{Ca}^{2+}\left(1.6 \pm 0.8 \mu \mathrm{g} \mathrm{m}^{-3}\right)$ and $\mathrm{Na}^{+}\left(0.7 \pm 0.8 \mu \mathrm{g} \mathrm{m}^{-3}\right)$, in contrast to those at Mt. Tai, where $\mathrm{NO}_{3}^{-}\left(20 \pm 14 \mu \mathrm{g} \mathrm{m}^{-3}\right)$ was the most abundant, followed by $\mathrm{SO}_{4}^{2-}\left(16 \pm 13 \mu \mathrm{g} \mathrm{m}^{-3}\right)$, $\mathrm{NH}_{4}^{+}\left(12 \pm 8.9 \mu \mathrm{g} \mathrm{m}^{-3}\right), \quad \mathrm{Ca}^{2+}\left(3.9 \pm 2.1 \mu \mathrm{g} \mathrm{m}^{-3}\right), \quad \mathrm{Cl}^{-}$ $\left(2.2 \pm 1.7 \mu \mathrm{g} \mathrm{m}^{-3}\right), \mathrm{K}^{+}\left(1.3 \pm 0.8 \mu \mathrm{g} \mathrm{m}^{-3}\right)$, and $\mathrm{Na}^{+}(0.7 \pm$ $0.4 \mu \mathrm{g} \mathrm{m}^{-3}$ ).

During the nonevent period more than $90 \%$ of $\mathrm{PM}_{10}$ samples collected at Mt. Hua showed that nitrate is lower than sulfate (Fig. 6a). However, around $80 \%$ of $\mathrm{PM}_{10}$ samples collected at Mt. Tai showed that nitrate is higher than sulfate

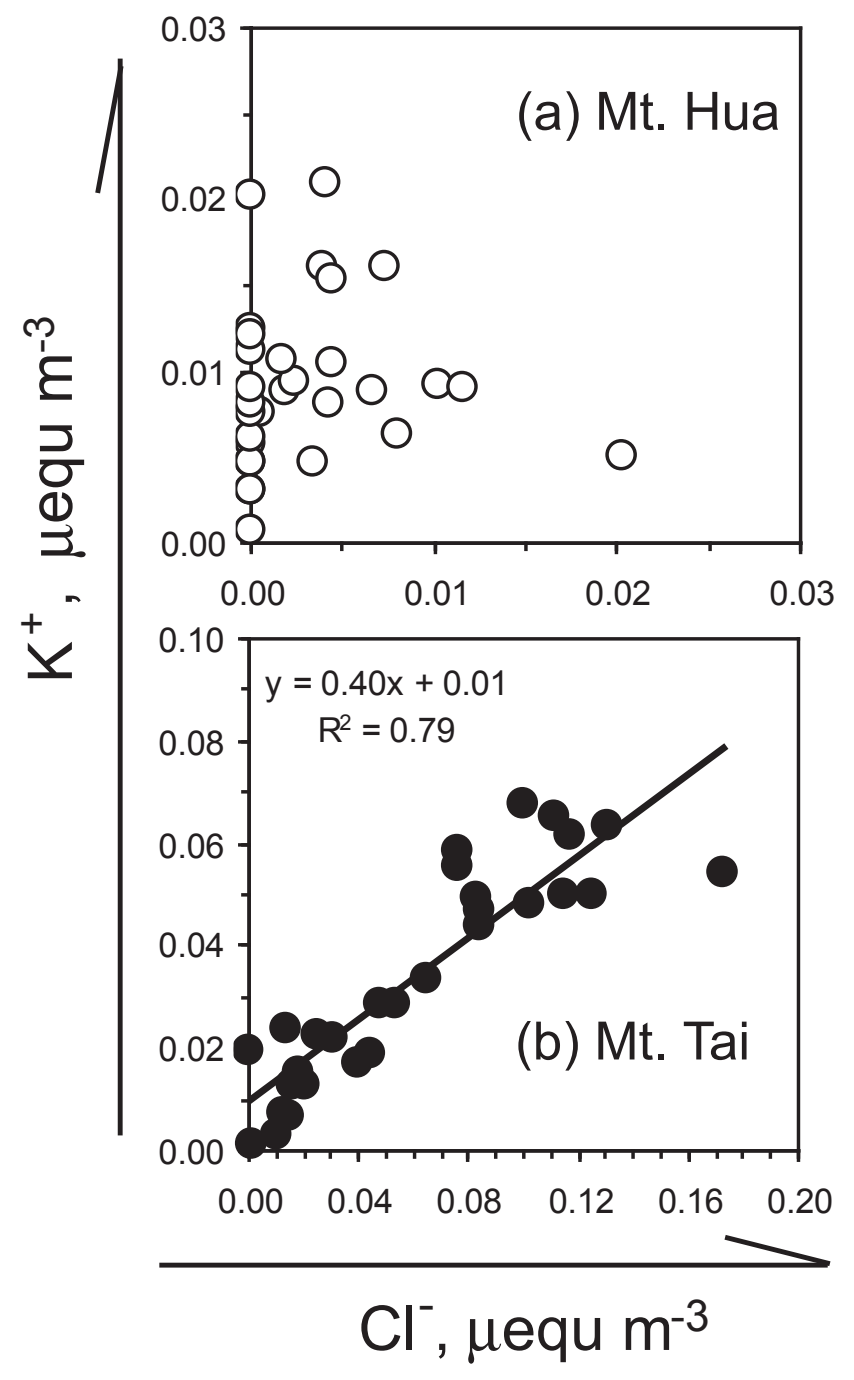

Fig. 5. Correlation of $\mathrm{K}^{+}$and $\mathrm{Cl}^{-}$in $\mathrm{PM}_{10}$ at Mt. Hua and Mt. Tai during the non-dust storm period.

(Fig. 6b). Coal is the major energy source in the country with more than 2.7 billion tons of coal being burned in 2003 (Aldhous, 2005). To improve the air quality Chinese government promulgated a strict law to reduce $\mathrm{SO}_{2}$ emission in 2005 . Thus the increasing rate of $\mathrm{SO}_{2}$ emission is expected to decrease. Concentrations of nitrogen oxides, on the other hand, have been increasing due to economic growth (Richter et al., 2005), leading to an enhanced nitrate aerosol in many urban areas especially in mega-cities such as Beijing and Shanghai with nitrate concentration being comparable and even higher than sulfate (Huang et al., 2010a, b; Pathak et al., 2009, 2010; Wang et al., 2006b). Compared to sulfate the more abundant nitrate in the Mt. Tai atmosphere are not only due to the high level of nitrogen oxides in the NCP region but also probably due to the unique atmosphere environment, because higher humidity and lower temperature of the mountaintop atmosphere are favorable for the transformation of $\mathrm{HNO}_{3}$ from 

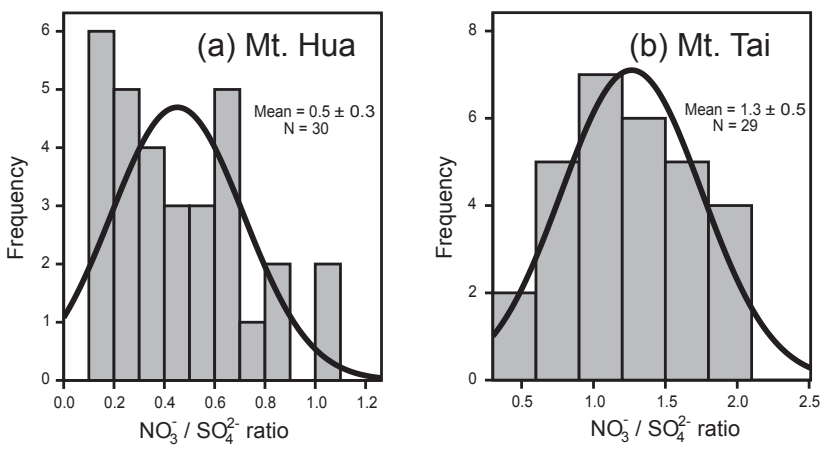

Fig. 6. Frequency of $\mathrm{PM}_{10}$ samples containing nitrate with a concentration higher than that of sulfate. (a) Mt. Hua: non-dust storm

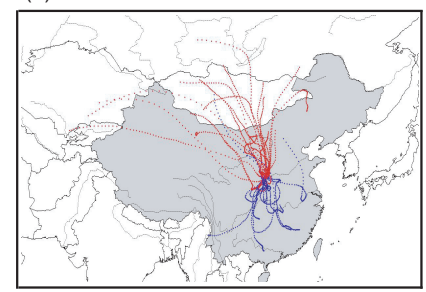

(b) Mt. Tai: non-dust storm

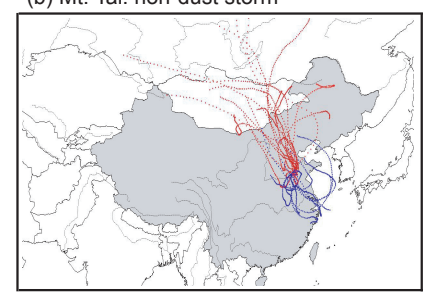

(c) Mt. Hua: dust storm I \& II

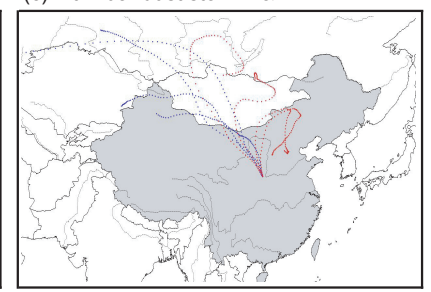

(d) Mt. Tai: dust storm II

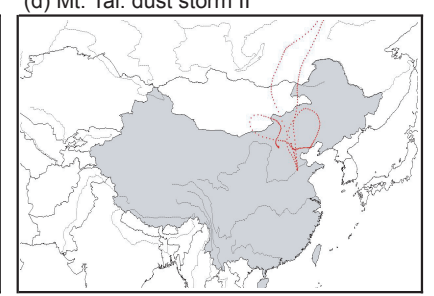

Fig. 7. 72-h backward trajectories of air masses arriving in Mt. Hua and Mt. Tai during the non-dust and the dust-storm periods (The blue trajectories in (c) represent the dust storm I (DSI) while the red trajectories in (c) and (d) represent the dust storm II (DSII)).

gas to solid phase. However, the fact that concentration of $\mathrm{NO}_{3}^{-}$exceeds over $\mathrm{SO}_{4}^{2-}$ clearly demonstrates that the atmospheric environment in east China is significantly changing.

Figure 7 plots the 72-h backward trajectories of air masses reaching the two sampling sites. Air masses at both sites during the non-dust storm period were transported from the south and north directions, respectively (Fig. 7a and b). Thus the corresponding samples can be classified as two groups, i.e., southerly and northerly. At the Mt. Hua site concentrations of $\mathrm{SO}_{4}^{2-}, \mathrm{Na}^{+}, \mathrm{NH}_{4}^{+}$and $\mathrm{K}^{+}$are higher in the southerly air masses than in the northerly (Table 3), while EC, OC and other major ions in both directions of air masses are comparable. In contrast, at Mt. Tai all species except for $\mathrm{F}^{-}$are equal or more abundant in the southerly air masses than in the northerly. Moreover, $\mathrm{pH}$ values showed that aerosols from south China are more acidic than those from north China especially in the Mt. Tai region (Table 3).

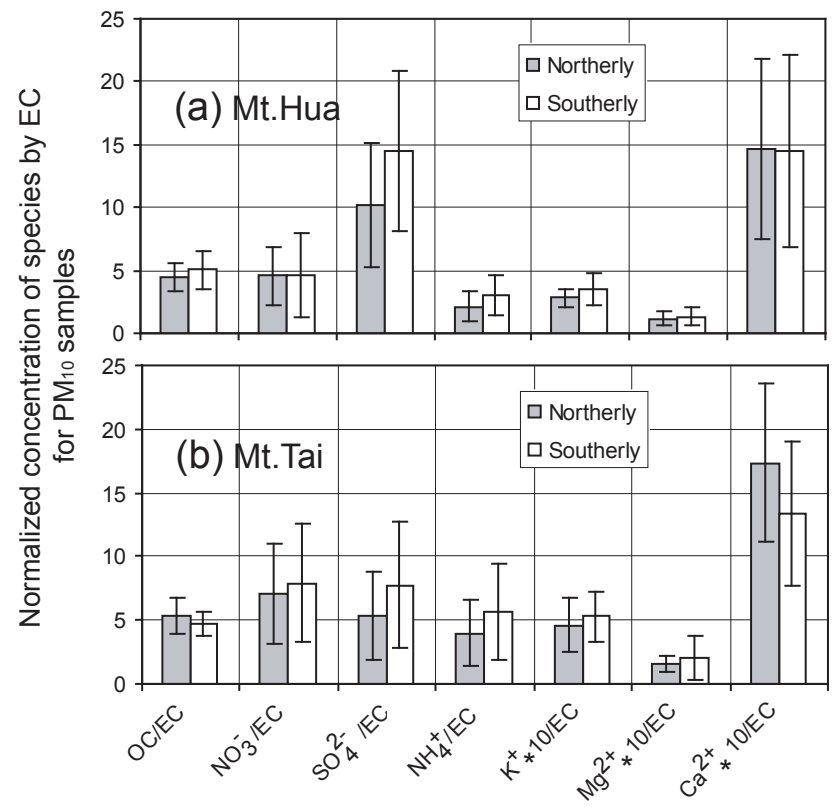

Fig. 8. Concentrations of species in $\mathrm{PM}_{10}$ normalized by EC at (a) Mt. Hua and (b) Mt. Tai during the non-dust storm period.

EC is chemically stable, thus the normalized concentrations of species by EC can be useful for recognizing the changes in chemical compositions of aerosols during transport. As shown in Fig. 8a and b, relative abundance of OC and $\mathrm{Ca}^{2+}$ to $\mathrm{EC}$ in the two mountain regions are similar. However, the ratios of $\mathrm{NO}_{3}^{-}, \mathrm{NH}_{4}^{+}$and $\mathrm{K}^{+}$to $\mathrm{EC}$ at $\mathrm{Mt}$. Hua are lower than those at Mt. Tai, again suggesting the high levels of nitrogen oxides, ammonia and biomass burning emission in east China. In contrast, the ratio of $\mathrm{SO}_{4}^{2-}$ to $\mathrm{EC}$ is higher at Mt. Hua than at Mt. Tai. The lower ratio of $\mathrm{SO}_{4}^{2-} / \mathrm{EC}$ at Mt. Tai (Fig. 8) can be explained by more vehicle exhausts in the east coastal region, which contain more EC and less $\mathrm{SO}_{2}$ compared to coal burning emissions (Gaffney and Marley, 2009; Wang et al., 2007; Xie et al., 2010). Sulfate strongly reflects solar radiation, whereas EC strongly absorbs solar radiation. Thus the net radiative forcing is determined by the relative amounts of sulfate and EC (Ramana et al., 2010). The lower ratio of $\mathrm{SO}_{4}^{2-}$ to EC suggests that climate-warming effect caused by aerosols may be more significant in the Mt. Tai area. A recent aircraft measurement (Xue et al., 2010) showed that boundary level $\mathrm{SO}_{2}$ in east coastal China is about 10 times higher than that in the inland region, but the free tropospheric level $(>1.5 \mathrm{~km}$ a.s.l) of $\mathrm{SO}_{2}$ in the east and inland parts of China are comparable, which could be one of the reasons why $\mathrm{SO}_{4}^{2-}$ presented a similar concentration in the two mountain areas. The ratios of $\mathrm{NO}_{3}^{-}, \mathrm{SO}_{4}^{2-}, \mathrm{NH}_{4}^{+}$and $\mathrm{K}^{+}$to $\mathrm{EC}$ at both sites are generally higher in the southerly air mass than in the northerly air mass, which is consistent with the observation for wintertime aerosols at Mt. Hua (Li et al., 2011). Figure 9 plots the 
Table 3. Concentrations of species in $\mathrm{PM}_{10}$ transported southerly and northerly at Mt. Hua and Mt. Tai during the non-dust storm period, $\mu \mathrm{g} \mathrm{m}^{-3}$.

\begin{tabular}{|c|c|c|c|c|c|c|}
\hline & \multicolumn{3}{|c|}{ Mt. Hua } & \multicolumn{3}{|c|}{ Mt. Tai } \\
\hline & $\begin{array}{r}\text { Southerly } \\
(\mathrm{n}=11)\end{array}$ & $\begin{array}{r}\text { Northerly } \\
(\mathrm{n}=19)\end{array}$ & $\mathrm{S} / \mathrm{N}^{\mathrm{a}}$ & $\begin{array}{r}\text { Southerly } \\
(\mathrm{n}=10)\end{array}$ & $\begin{array}{r}\text { Northerly } \\
(\mathrm{n}=19)\end{array}$ & $\mathrm{S} / \mathrm{N}^{\mathrm{a}}$ \\
\hline $\mathrm{PM}_{10}$ & $68 \pm 30$ & $74 \pm 27$ & 0.9 & $175 \pm 50$ & $151 \pm 65$ & 1.2 \\
\hline $\mathrm{OC}$ & $4.7 \pm 2.0$ & $5.1 \pm 1.0$ & 0.9 & $12 \pm 4.7$ & $13 \pm 6.5$ & 1.0 \\
\hline $\mathrm{EC}$ & $1.1 \pm 0.6$ & $1.2 \pm 0.4$ & 0.9 & $2.7 \pm 1.2$ & $2.8 \pm 2.4$ & 1.0 \\
\hline$\Delta \mathrm{pH}^{\mathrm{b}}$ & $-0.2 \pm 0.6$ & $0.1 \pm 0.5$ & - & $-1.5 \pm 0.8$ & $-1.0 \pm 0.6$ & - \\
\hline $\mathrm{F}^{-}$ & $0.1 \pm 0.1$ & $0.1 \pm 0.0$ & 0.8 & $0.1 \pm 0.1$ & $0.2 \pm 0.1$ & 0.6 \\
\hline $\mathrm{Cl}^{-}$ & $0.1 \pm 0.0$ & $0.2 \pm 0.2$ & 0.6 & $2.6 \pm 1.8$ & $2.0 \pm 1.6$ & 1.3 \\
\hline $\mathrm{NO}_{3}^{-}$ & $4.8 \pm 4.5$ & $5.6 \pm 3.6$ & 0.9 & $23 \pm 16$ & $18 \pm 13$ & 1.3 \\
\hline $\mathrm{SO}_{4}^{2-}$ & $13 \pm 7.2$ & $12 \pm 6.8$ & 1.1 & $21 \pm 15$ & $14 \pm 11$ & 1.6 \\
\hline $\mathrm{Na}^{+}$ & $1.1 \pm 0.8$ & $0.5 \pm 0.7$ & 2.0 & $0.7 \pm 0.5$ & $0.7 \pm 0.3$ & 1.0 \\
\hline $\mathrm{NH}_{4}^{+}$ & $2.7 \pm 1.3$ & $2.4 \pm 1.2$ & 1.1 & $16 \pm 11$ & $10 \pm 7.4$ & 1.6 \\
\hline $\mathrm{K}^{+}{ }^{4}$ & $0.4 \pm 0.2$ & $0.3 \pm 0.2$ & 1.1 & $1.5 \pm 0.7$ & $1.3 \pm 0.9$ & 1.2 \\
\hline $\mathrm{Mg}^{2+}$ & $0.1 \pm 0.1$ & $0.1 \pm 0.1$ & 0.9 & $0.6 \pm 0.5$ & $0.4 \pm 0.3$ & 1.4 \\
\hline $\mathrm{Ca}^{2+}$ & $1.5 \pm 1.0$ & $1.7 \pm 0.7$ & 0.8 & $3.6 \pm 1.9$ & $4.1 \pm 2.2$ & 0.9 \\
\hline Total ions & $23 \pm 13$ & $23 \pm 9.9$ & 1.0 & $69 \pm 45$ & $50 \pm 34$ & 1.4 \\
\hline
\end{tabular}

${ }^{\mathrm{a}}$ Ratio of average concentration of southerly to that of northerly; ${ }^{\mathrm{b}} \mathrm{pH}=\mathrm{pH}$ of water-extracts of the samples - $\mathrm{pH}$ of water-extracts of the filed blanks.

equivalent ratio of each species to the total of the three ions. The percentage of $\mathrm{NH}_{4}^{+}$is higher at Mt. Tai than at Mt. Hua during the non-dust periods (Fig. 9a), indicating that in the Mt. Hua atmosphere more $\mathrm{NO}_{3}^{-}$and $\mathrm{SO}_{4}^{2-}$ are neutralized by soil dust derived alkaline ions such as $\mathrm{Ca}^{2+}$ and $\mathrm{Mg}^{2+}$, in contrast to Mt. Tai, where more $\mathrm{NO}_{3}^{-}$and $\mathrm{SO}_{4}^{2-}$ are neutralized by $\mathrm{NH}_{4}^{+}$.

To further recognize the difference of aerosol composition between the two mountain atmospheres, an EC tracer method as follow was used to approximately estimate primary organic carbon (POC) and secondary organic carbon (SOC) in the $\mathrm{PM}_{10}$ samples (Castro et al., 1999; Chu, 2005; Yu et al., 2009).

$\mathrm{POC}=\mathrm{EC} \times\left(\frac{\mathrm{OC}}{\mathrm{EC}}\right)_{\min }$

$\mathrm{SOC}=\mathrm{OC}-\mathrm{POC}$

Where the $(\mathrm{OC} / \mathrm{EC})_{\min }$ is the minimum ratio of $\mathrm{OC} / \mathrm{EC}$ for the samples at each site. Results based on the calculation showed that throughout the non-dust storm period SOC/POC ratio was $0.5 \pm 0.4$ at Mt. Hua and $0.9 \pm 0.5$ at Mt. Tai, while $\mathrm{SOC} / \mathrm{EC}$ ratio at the sites was $1.5 \pm 1.3$ and $2.4 \pm 1.3$, respectively, suggesting that carbonaceous aerosols in east coastal China is more oxidized, which is consistent with the enhanced concentration of glyoxal, a photo-oxidation product of volatile organic compounds (VOCs), over the NCP region as reported by satellite observation (Wittrock et al., 2006) and is ascribed to the high levels of oxidants such as $\mathrm{O}_{3}$
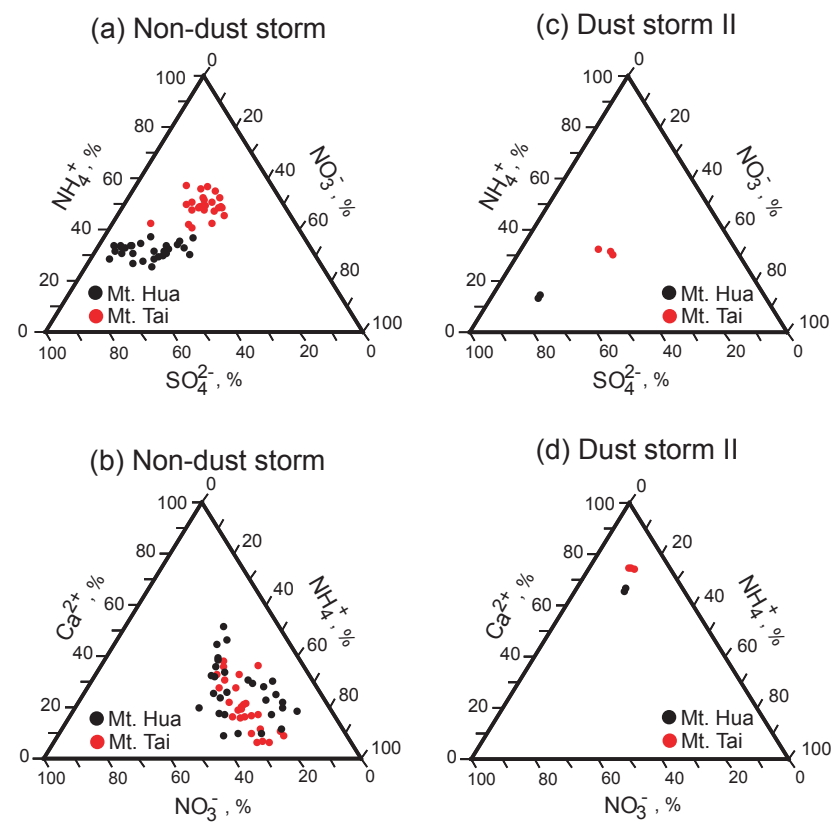

Fig. 9. Ternary diagrams for the equivalent ratio of major ions in $\mathrm{PM}_{10}$ samples during (a), (b) the non-dust and (c), (d) the dust storm II periods.

and $\mathrm{NO}_{\mathrm{x}}$ and VOCs in the region (Akimoto, 2003; Fu et al., 2008; Hatakeyama et al., 2005; Streets and Waldhoff, 2000; Takiguchi et al., 2008). The ratio of SOC/POC at Mt. Hua is also slightly higher than that $(0.4 \pm 0.4)$ in Baoji 
(Wang et al., 2010), a city nearby Mt. Hua, further indicating that mountain aerosols are more aged compared to those on ground surface.

\subsubsection{Dust storm II on 24 April}

As seen in Table 2, a moderate dust storm event, named as Dust storm I (DSI), occurred on 20 April at Mt. Hua with concentrations of 365 and $173 \mu \mathrm{g} \mathrm{m}^{-3}$ for TSP and $\mathrm{PM}_{10}$, respectively. Four days later an intensive dust storm event (Dust storm II, DSII), originating from Gobi desert, simultaneously reached Mt. Hua and Mt. Tai with averaged 3$\mathrm{h}$ concentrations of TSP and $\mathrm{PM}_{10}$ being $689 \pm 355$ and $506 \pm 303 \mu \mathrm{g} \mathrm{m}^{-3}$ at Mt. Hua and $1759 \pm 542$ and $1343 \pm$ $450 \mu \mathrm{g} \mathrm{m}^{-3}$ at Mt. Tai, respectively. Here we only compare the composition of DSII samples to discuss difference in the impact of the event on the two alpine atmospheres. Compositions of chemicals in the highest loading of 3-h $\mathrm{PM}_{10}$ samples collected during DSII are shown in Table 4. $\Delta \mathrm{pH}$ values showed that even in the dust period aerosols at Mt. Tai are still more acidic than those at Mt. Hua. EC in the 3-h sample at Mt. Hua was $1.1 \mu \mathrm{g} \mathrm{m}^{-3}$ but undetectable at Mt. Tai, whereas $\mathrm{SO}_{4}^{2-}$ and $\mathrm{Na}^{+}$showed a similar concentration at both sites (Table 4). $\mathrm{NO}_{3}^{-}, \mathrm{NH}_{4}^{+}, \mathrm{Ca}^{2+}$ and other ions in the DSII samples at Mt. Tai were 1-5 times more than those at Mt. Hua. Based on the characterization of single Asian dust particle, Sullivan et al. (2007) found that Fe-rich Asian dust particles were closely associated with secondary sulfate whereas Ca-rich particles could contain secondary sulfate and nitrate. Therefore, high concentration of $\mathrm{Ca}^{2+}$ observed during the event at Mt. Tai was probably caused by enhanced heterogeneous reactions of $\mathrm{H}_{2} \mathrm{SO}_{4}, \mathrm{HNO}_{3}$ and their precursors (e.g., $\mathrm{NO}_{2}, \mathrm{~N}_{2} \mathrm{O}_{5}$, and $\mathrm{SO}_{2}$ ) with dust particles.

Compared to those during the non-dust storm period, the average concentrations of particle mass, $\mathrm{OC}, \mathrm{Na}^{+}, \mathrm{K}^{+}$, $\mathrm{Mg}^{2+}$ and $\mathrm{Ca}^{2+}$ of $\mathrm{PM}_{10}$ at both sites increased by a factor of 1-9 during the DSII period with $\mathrm{EC}, \mathrm{NO}_{3}^{-}$and $\mathrm{NH}_{4}^{+}$ decreasing by $20-80 \%$. Interestingly, during both the event and the non-event time $\mathrm{SO}_{4}^{2-}$ did not change significantly at the two alpine sites, further suggesting a homogeneous distribution of free tropospheric $\mathrm{SO}_{2}$ in the DSII pathways. Due to an additional input of $\mathrm{Ca}^{2+}$ the relative abundance of $\mathrm{NH}_{4}^{+}$to the total equivalent of $\mathrm{NH}_{4}^{+}, \mathrm{NO}_{3}^{-}$and $\mathrm{SO}_{4}^{2-}$ significantly decreased (Fig. 9c), compared with those during the non-dust period (Fig. 9a), and the abundance of $\mathrm{Ca}^{2+}$ relative to the total of $\mathrm{Ca}^{2+}, \mathrm{NH}_{4}^{+}$, and $\mathrm{NO}_{3}^{-}$sharply increased, especially at Mt. Tai (Fig. 9b and d), indicating that the existence of $\mathrm{Ca}^{2+}$ is unfavorable for the formation of $\mathrm{NH}_{4}^{+}$, because mineral dust shifts ammonia from the particle to gas phase by changing the aerosol from a cation- to anion- limited state due to the presence of alkaline species (Song and Carmichael, 1999).
Table 4. Concentrations of species in the highest loading of 3-h $\mathrm{PM}_{10}$ sample during the dust storm II event occurring on 24 April, $\mu \mathrm{g} \mathrm{m}^{-3}$.

\begin{tabular}{lccc}
\hline & Mt. Hua & Mt. Tai & Mt. Tai/Mt. Hua \\
\hline $\mathrm{PM}_{10}$ & 740 & 1797 & 2.4 \\
$\mathrm{OC}$ & 30 & 52 & 1.7 \\
$\mathrm{EC}$ & 1.1 & 0.0 & 0.0 \\
$\mathrm{pH}^{\mathrm{a}}$ & 1.0 & 0.3 & 0.2 \\
$\mathrm{~F}^{-}$ & 0.1 & 0.4 & 4.6 \\
$\mathrm{Cl}^{-}$ & 1.7 & 2.7 & 1.6 \\
$\mathrm{NO}_{3}^{-}$ & 5.4 & 15 & 2.8 \\
$\mathrm{SO}_{4}^{2-}$ & 20 & 20 & 1.0 \\
$\mathrm{Na}^{+}$ & 4.4 & 4.1 & 0.9 \\
$\mathrm{NH}_{4}^{+}$ & 1.3 & 5.7 & 4.2 \\
$\mathrm{~K}^{+}$ & 0.8 & 2.5 & 3.3 \\
$\mathrm{Mg}^{2+}$ & 0.6 & 1.4 & 2.3 \\
$\mathrm{Ca}^{2+}$ & 6.0 & 31 & 5.2 \\
\hline $\mathrm{Total}^{2+}$ ions & 40 & 84 & 2.1 \\
\hline
\end{tabular}

${ }^{\mathrm{a}} \mathrm{pH}=\mathrm{pH}$ of water-extracts of the samples $-\mathrm{pH}$ of water-extracts of the filed blanks.

\subsubsection{Comparison with urban aerosols}

As shown in Table 5, the springtime concentrations of $\mathrm{NO}_{3}^{-}$ and $\mathrm{SO}_{4}^{2-}$ in the Mt. Hua air are 2-5 times lower than those in Xi'an, Beijing and Shanghai, three mega-cities in China, while concentrations of $\mathrm{NO}_{3}^{-}$and $\mathrm{SO}_{4}^{2-}$ at Mt. Tai are similar to those in Shanghai and about 30-50\% lower than those in $\mathrm{Xi}^{\prime}$ an and Beijing. Compared to the three cities $\mathrm{NH}_{4}^{+}$is much lower at Mt. Hua but comparable and even higher at Mt. Tai. Concentration ratio of $\mathrm{NO}_{3}^{-} / \mathrm{SO}_{4}^{2-}$ is highest at Mt. Tai, followed by Beijing, Shanghai, Xi' an and Mt. Hua, being coincident with a higher level of nitrogen oxides in east China (Richter et al., 2005). The ratio of $\mathrm{NO}_{3}^{-}$to $\mathrm{SO}_{4}^{2-}$ at Mt. Hua is $50 \%$ lower than that in Xi' an, a nearby city (see Fig. 1). In contrast, the ratio at Mt. Tai is $30 \%$ higher than that in Beijing and Shanghai (Table 5), two mega-cities located in east coastal China. Such an opposite vertical pattern between the mountains and nearby cities suggests that the atmospheric environment in the Mt. Tai area is favorable to form nitrate aerosol, largely due to the high level of nitrogen oxides in the NCP region and the advantaged meteorological conditions of lower temperature and higher humidity of the mountain air.

\subsection{Size distribution}

\subsubsection{Non-dust storm period}

As seen in Fig. 10a and b, particle mass size distribution during the non-dust storm period at Mt. Hua was the same as that at Mt. Tai, showing a bimodal size distribution with two equivalent peaks in the fine $(<2.1 \mu \mathrm{m})$ and coarse $(\geq 2.1 \mu \mathrm{m})$ 
Table 5. Concentrations of inorganic ions in the mountain and urban atmosphere over China, $\mu \mathrm{g} \mathrm{m}^{-3}$.

\begin{tabular}{|c|c|c|c|c|c|c|c|c|c|}
\hline & Year & Size & $\mathrm{NO}_{3}^{-}$ & $\mathrm{SO}_{4}^{2-}$ & $\mathrm{NH}_{4}^{+}$ & $\mathrm{Ca}^{2+}$ & $\mathrm{K}^{+}$ & $\mathrm{NO}_{3}^{-} / \mathrm{SO}_{4}^{2-}$ & Reference \\
\hline \multicolumn{10}{|c|}{ I. Mountains } \\
\hline Mt. Hua & Spring, 2009 & $\mathrm{PM}_{10}$ & 5.0 & 13 & 2.5 & 1.6 & 0.3 & 0.4 & This study \\
\hline Mt. Tai & Spring 2009 & $\mathrm{PM}_{10}$ & 20 & 16 & 12 & 3.9 & 1.3 & 1.3 & This study \\
\hline \multicolumn{10}{|c|}{ II. Mega-cities } \\
\hline Xi'an & Spring 2009 & $\mathrm{PM}_{10}$ & 27 & 32 & 11 & 8.0 & 2.0 & 0.8 & Wang et al. (2010b) \\
\hline Beijing & 2001-2004 & TSP & 30 & 31 & 17 & 8.4 & 2.0 & 1.0 & Wang et al. (2006a) \\
\hline Beijing & 12-13 July 2005 & $\mathrm{PM}_{2.5}$ & $20-50$ & $50 \pm 10$ & $\mathrm{na}^{\mathrm{a}}$ & $\mathrm{na}^{\mathrm{a}}$ & $\mathrm{na}^{\mathrm{a}}$ & $0.4-1.0$ & Pathak et al. (2010) \\
\hline Shanghai & Spring 2006 & TSP & 22 & 21 & 7.0 & 5.9 & 0.73 & 1.0 & Wang et al. (2006b) \\
\hline Shanghai & 2-3 July 2005 & $\mathrm{PM}_{2.5}$ & $20-70$ & $50 \pm 10$ & $\mathrm{na}^{\mathrm{a}}$ & $\mathrm{na}^{\mathrm{a}}$ & $\mathrm{na}^{\mathrm{a}}$ & $0.4-1.2$ & Pathak et al. (2010) \\
\hline
\end{tabular}

a na: not available.

(I) Non-dust period

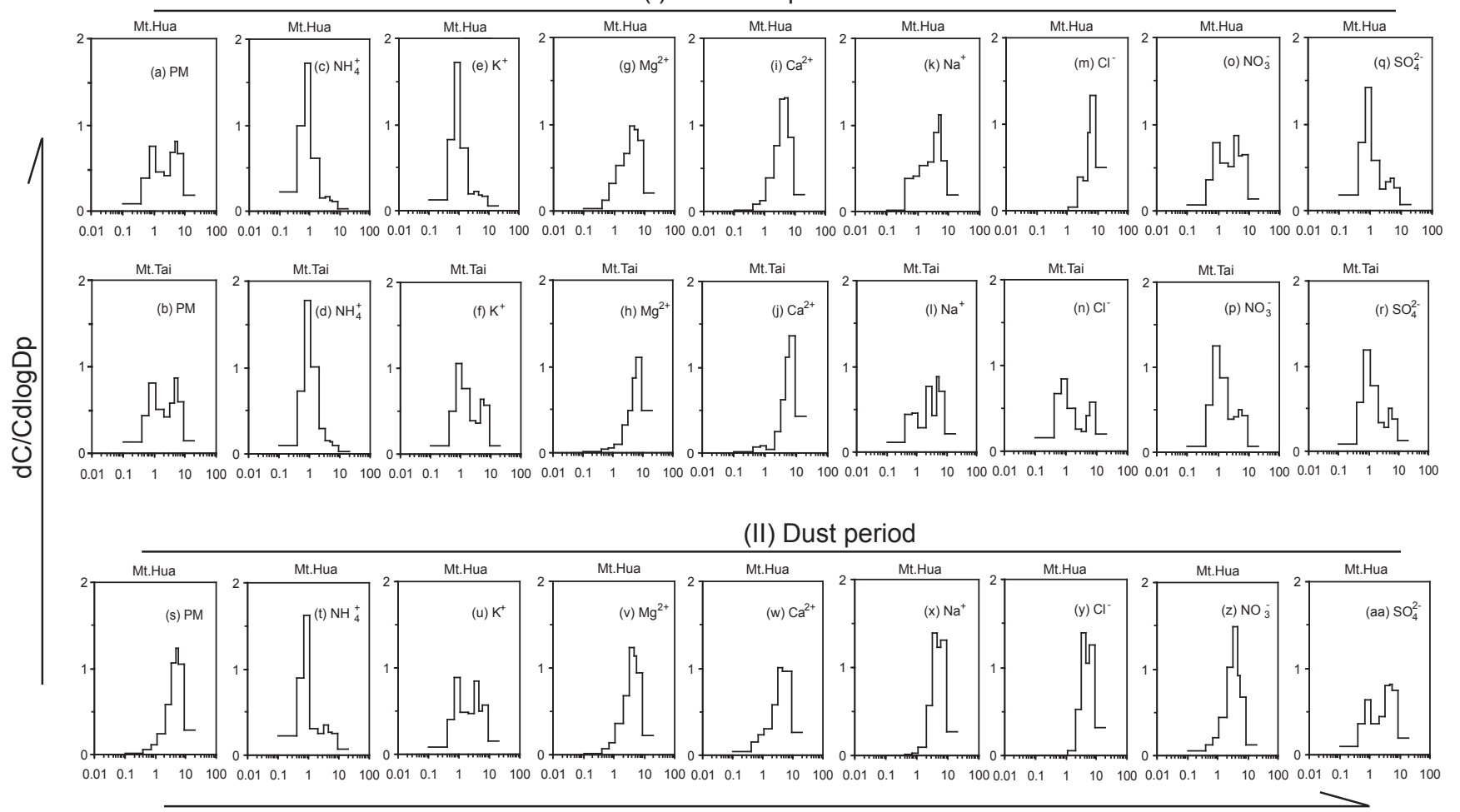

Particle size, Dp $(\mu \mathrm{m})$

Fig. 10. Size distributions of particles and inorganic ions during (I) non-dust storm period and (II) dust storm period.

ranges. Ammonium presented a similar unimodal pattern at both sites, dominating in the fine mode (Fig. 10c and d). $\mathrm{K}^{+}$showed a bimodal size distribution at the sites (Fig. 10e and $\mathrm{f}$ ), but coarse mode of potassium ion at Mt. Tai was much more pronounced. A similar pattern with $\mathrm{K}^{+}$can be seen for $\mathrm{Cl}^{-}$at Mt. Tai (Fig. 10n), together with the strong correlation of $\mathrm{K}^{+}$and $\mathrm{Cl}^{-}$in $\mathrm{PM}_{10}$ mentioned above, again demonstrating biomass-burning emission as their ma- jor source. $\mathrm{Mg}^{2+}, \mathrm{Ca}^{2+}$ and $\mathrm{Na}^{+}$at both sites dominated in coarse mode (Fig. 10g-1), because they are mostly derived from soil/dust. But the significant amount of $\mathrm{Na}^{+}$presenting in the fine size range indicates an importance of additional sources other than soil/dust (Fig. 10k and 1). $\mathrm{Cl}^{-}$at Mt. Hua was almost entirely present in coarse particles, in contrast to the case at Mt. Tai, where $\mathrm{Cl}^{-}$largely occurs in the fine size range (Fig. $10 \mathrm{~m}$ and $\mathrm{n}$ ). $\mathrm{Cl}^{-}$at $\mathrm{Mt}$. Hua, along with 
other cations such as $\mathrm{Na}^{+}$and $\mathrm{Mg}^{2+}$, probably originated in part from dried salt lakes in north and northwest China. Nitrate showed a bimodal distribution with two comparable peaks at Mt. Hua in the size ranges of 0.7-1.1 and $>2.1 \mu \mathrm{m}$ (Fig. 10o), and with a predominant peak in the fine mode and a small peak in the coarse mode at Mt. Tai (Fig. 10p). $64 \%$ of $\mathrm{NO}_{3}^{-}$was present in the coarse particles at Mt. Hua, while only $39 \%$ of $\mathrm{NO}_{3}^{-}$was present in the coarse particles at Mt. Tai (Table 6). The increased coarse fraction of nitrate at Mt. Hua can be explained by an increased adsorption of gaseous $\mathrm{HNO}_{3}$ onto alkaline particles due to more dust in the region (Takiguchi et al., 2008). As seen in Table 2, $\mathrm{NH}_{4}^{+}\left(12 \pm 8.9 \mu \mathrm{g} \mathrm{m}^{-3}\right)$ at Mt. Tai is 4 times higher than that $\left(2.5 \pm 1.3 \mu \mathrm{g} \mathrm{m}^{-3}\right)$ at Mt. Hua, which means $\mathrm{NH}_{3}$ is also much more abundant at Mt. Tai than at Mt. Hua, because in China large amount of $\mathrm{NH}_{3}$ is emitted through agricultural activities such as fertilizer application (Streets et al., 2003; Streets and Waldhoff, 2000) in addition to biomass burning emissions (Andreae et al., 1998). Particulate $\mathrm{NO}_{3}^{-}$can be formed by a gas phase reaction of $\mathrm{HNO}_{3}$ with $\mathrm{NH}_{3}$ and enriched in fine particles (Seinfeld and Pandis, 1998), which is more significant at Mt. Tai due to the high level of $\mathrm{NH}_{3}$. However, due to the relatively lower level of $\mathrm{NH}_{3}$, gaseous $\mathrm{HNO}_{3}$ in the Mt. Hua atmosphere has more chance to absorb onto alkaline dust. As a result, the coarse mode of $\mathrm{NO}_{3}^{-}$at Mt. Hua is more abundant than that at Mt. Tai. Sulfate at the two alpine regions exhibited a similar bimodal pattern with a large peak in the fine mode and a small peak in the coarse mode (Fig. 10q and r).

\subsubsection{Dust storm on 24 April}

As shown in Fig. 10s-aa, the size distribution patterns of particles and all ions were altered during the dust storm event on 24 April with an increase in the coarse range, especially for $\mathrm{PM}, \mathrm{K}^{+}, \mathrm{Na}^{+}, \mathrm{NO}_{3}^{-}$and $\mathrm{SO}_{4}^{2-}$. Size distribution of $\mathrm{PM}$ and $\mathrm{NO}_{3}^{-}$during the event changed from a bimodal pattern (Fig. 10a, and o) into a unimodal one in the coarse mode (Fig. 11s and z). Sulfate still exhibited a bimodal pattern, but its fine fraction significantly decreased compared to that in the non-dust storm period (Fig. 10q and aa). Such changes in size distribution pattern indicate that gas-to-particle conversion of $\mathrm{NO}_{3}^{-}$and $\mathrm{SO}_{4}^{2-}$ affect both sub- and supermicrometer aerosol modes by redirecting much of the deposition that would normally occur on the accumulation mode to the larger dust particles during the event (Seinfeld et al., 2004; Takiguchi et al., 2008). Other ions also showed an increase in the coarse mode when the dust was present, especially for $\mathrm{K}^{+}, \mathrm{Na}^{+}$and $\mathrm{Cl}^{-}$, with a significantly diminished and even disappeared mass peak in the fine range during the episode (see Fig. 10u, $x$ and $y$ ).

Different compounds are of different solubility, for example, $\mathrm{Ca}\left(\mathrm{NO}_{3}\right)_{2}$ and $\mathrm{CaCl}_{2}$ are highly soluble and much more hygroscopic than other insoluble or slightly soluble calcium salts like $\mathrm{CaCO}_{3}, \mathrm{CaSO}_{4}$, and $\mathrm{CaC}_{2} \mathrm{O}_{4}$ (Sullivan et al., 2009;
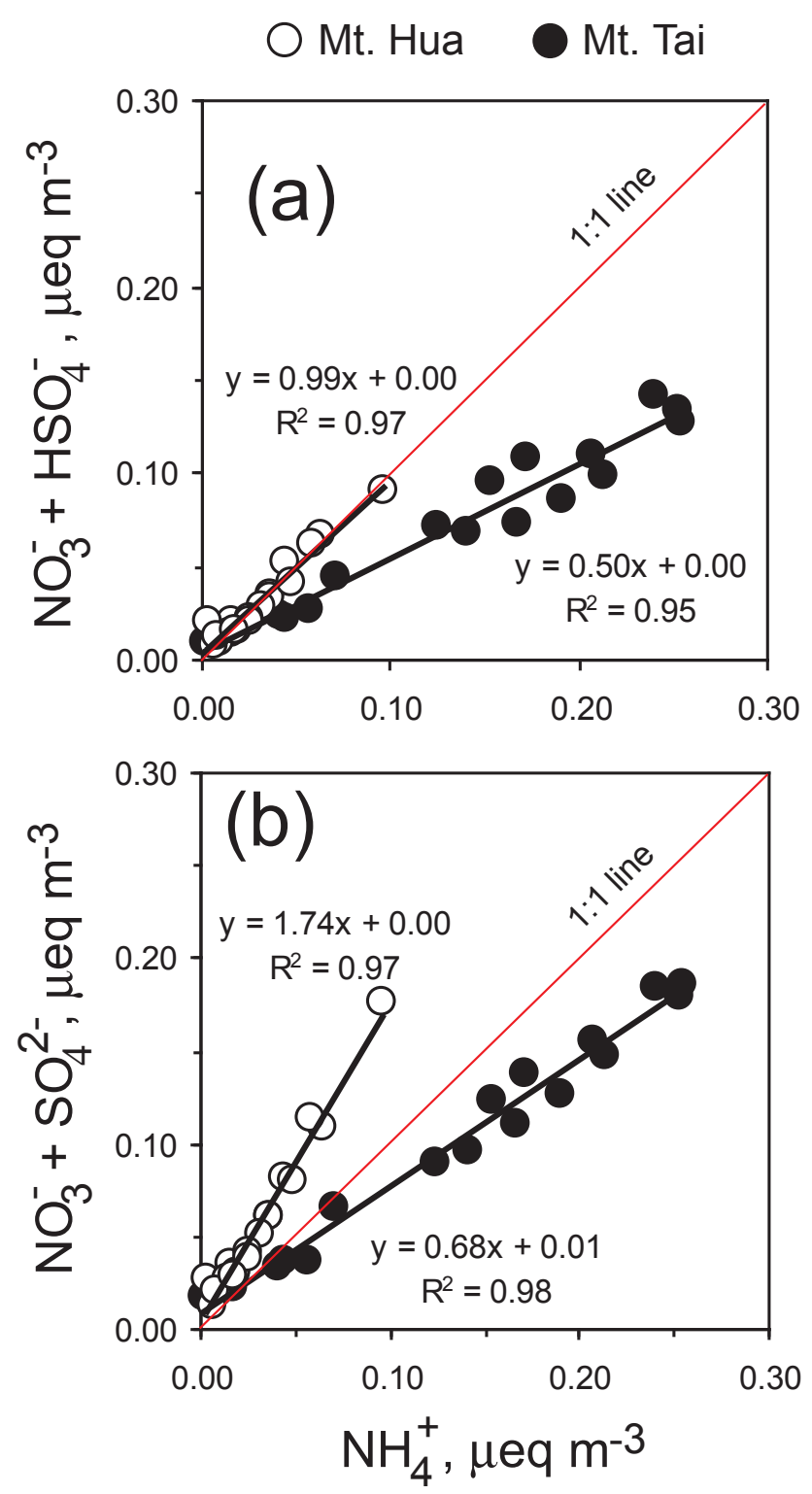

Fig. 11. Equivalent ratios of ammonium to (a) the sum of nitrate and bisulfate and (b) the sum of nitrate and sulfate in particles with a diameter less than $2.1 \mu \mathrm{m}$ at Mt. Hua and Mt. Tai during the whole sampling time including the non-dust storm and dust storm periods.

Tobo et al., 2010), affecting a particle's ability to activate as cloud condensation nuclei (Tobo et al., 2010). Thus, it is indispensable to investigate the chemical forms in which major ions exit in the particles. As shown in Table 6, during the nonevent and the event periods $\mathrm{NO}_{3}^{-}, \mathrm{SO}_{4}^{2-}$ and $\mathrm{NH}_{4}^{+}$are the three major ions in the fine range $(<2.1 \mu \mathrm{m})$, although only $22 \%$ of nitrate centered within this mode during the dust storm period. In contrast, $\mathrm{NO}_{3}^{-}, \mathrm{SO}_{4}^{2-}$ and $\mathrm{Ca}^{2+}$ are the three most abundant ions in the coarse size range $(>2.1 \mu \mathrm{m})$ in both nonevent and event time. Here, therefore, we investigate the specific chemical forms in fine particles for $\mathrm{NO}_{3}^{-}$, 
Table 6. Averaged concentration of inorganic ions in each stage at Mt. Hua and Mt. Tai during the non-dust storm and dust storm periods in spring 2009, $\mu \mathrm{g} \mathrm{m}^{-3}$.

\begin{tabular}{|c|c|c|c|c|c|c|c|c|c|}
\hline Size, $\mu \mathrm{m}$ & $\mathrm{F}^{-}$ & $\mathrm{Cl}^{-}$ & $\mathrm{NO}_{3}^{-}$ & $\mathrm{SO}_{4}^{2-}$ & $\mathrm{Na}^{+}$ & $\mathrm{NH}_{4}^{+}$ & $\mathrm{K}^{+}$ & $\mathrm{Mg}^{2+}$ & $\mathrm{Ca}^{2+}$ \\
\hline \multicolumn{10}{|c|}{ I. Non-dust storm } \\
\hline \multicolumn{10}{|c|}{ (a) Mt. Hua $(\mathrm{n}=4)$} \\
\hline$>9.0$ & $0.01(33)^{\mathrm{a}}$ & $0.06(55)$ & $0.72(14)$ & $1.01(7)$ & $0.10(27)$ & $0.09(3)$ & $0.02(5)$ & $0.04(22)$ & $0.56(25)$ \\
\hline $5.8-9.0$ & $0.01(25)$ & $0.02(26)$ & $0.60(14)$ & $0.65(5)$ & $0.05(17)$ & $0.06(2)$ & $0.01(3)$ & $0.02(16)$ & 0.42 (19) \\
\hline $4.7-5.8$ & $0.00(6)$ & $0.01(6)$ & $0.29(7)$ & $0.44(3)$ & $0.05(9)$ & 0.03 & $0.01(2)$ & $0.01(9)$ & $0.23(10)$ \\
\hline $3.3-4.7$ & $0.01(21)$ & $0.01(6)$ & $0.67(15)$ & $0.63(5)$ & $0.05(14)$ & $0.07(3)$ & $0.01(3)$ & $0.02(15)$ & $0.36(16)$ \\
\hline $2.1-3.3$ & $0.00(8)$ & $0.01(6)$ & $0.50(11)$ & $0.66(5)$ & $0.04(8)$ & $0.09(3)$ & $0.02(4)$ & $0.02(13)$ & $0.26(12)$ \\
\hline $1.1-2.1$ & $0.00(5)$ & $0.00(1)$ & $0.71(14)$ & $2.46(16)$ & $0.05(11)$ & $0.57(17)$ & $0.08(21)$ & $0.02(15)$ & $0.15(7)$ \\
\hline $0.7-1.1$ & $0.00(1)$ & $0.00(0)$ & $0.72(14)$ & $4.07(28)$ & $0.03(6)$ & $1.00(34)$ & $0.13(34)$ & $0.01(6)$ & $0.08(4)$ \\
\hline $0.4-0.7$ & $0.00(0)$ & $0.00(0)$ & $0.39(8)$ & 2.47 (19) & $0.03(7)$ & $0.63(24)$ & $0.07(20)$ & $0.00(3)$ & $0.07(3)$ \\
\hline$<0.4$ & $0.00(0)$ & $0.00(0)$ & $0.16(4)$ & $1.27(11)$ & $0.00(1)$ & $0.32(13)$ & $0.03(8)$ & $0.00(2)$ & $0.05(3)$ \\
\hline \multicolumn{10}{|c|}{ (b) Mt. Tai $(n=5)$} \\
\hline$>9.0$ & $0.07(40)$ & $0.42(30)$ & $1.21(7)$ & $2.35(12)$ & $0.31(20)$ & $0.10(1)$ & 0.19 (10) & $0.25(51)$ & $2.06(44)$ \\
\hline $5.8-9.0$ & $0.04(24)$ & $0.22(11)$ & $1.50(7)$ & $1.29(7)$ & $0.18(13)$ & $0.24(2)$ & $0.20(10)$ & $0.10(21)$ & $1.21(27)$ \\
\hline $4.7-5.8$ & $0.02(10)$ & $0.08(2)$ & $0.81(4)$ & $0.81(4)$ & $0.11(7)$ & $0.16(1)$ & $0.11(5)$ & $0.04(8)$ & 0.47 (10) \\
\hline $3.3-4.7$ & $0.02(13)$ & 0.07 (2) & $1.15(6)$ & $0.78(4)$ & $0.09(7)$ & $0.31(3)$ & $0.10(5)$ & $0.04(8)$ & 0.45 (10) \\
\hline $2.1-3.3$ & $0.01(4)$ & $0.11(3)$ & $1.35(7)$ & $1.19(7)$ & $0.20(17)$ & $0.73(6)$ & $0.14(8)$ & $0.03(6)$ & $0.23(5)$ \\
\hline $1.1-2.1$ & $0.01(4)$ & 0.29 (14) & $4.43(24)$ & $3.90(22)$ & $0.11(10)$ & $3.67(30)$ & $0.39(23)$ & $0.01(3)$ & $0.06(1)$ \\
\hline $0.7-1.1$ & $0.00(3)$ & 0.35 (17) & $4.40(24)$ & $4.17(24)$ & $0.12(9)$ & $3.92(32)$ & $0.38(21)$ & 0.01 & 0.07 (1) \\
\hline $0.4-0.7$ & $0.00(2)$ & $0.34(15)$ & $2.41(13)$ & 2.49 (14) & $0.14(11)$ & $2.27(18)$ & $0.22(12)$ & $0.01(1)$ & 0.07 (1) \\
\hline$<0.4$ & $0.00(0)$ & $0.20(6)$ & $0.77(4)$ & $0.97(5)$ & $0.09(7)$ & $0.72(6)$ & $0.10(5)$ & 0.00 & 0.03 (1) \\
\hline
\end{tabular}

II. Dust storm

(a) Mt. Hua $(\mathrm{n}=1)$

\begin{tabular}{llllllllll}
\hline$>9.0$ & $0.01(23)$ & $0.22(33)$ & $0.37(13)$ & $2.03(20)$ & $0.36(28)$ & $0.05(7)$ & $0.04(16)$ & $0.08(23)$ & $0.93(21)$ \\
$5.8-9.0$ & $0.01(18)$ & $0.10(24)$ & $0.37(13)$ & $1.43(14)$ & $0.32(25)$ & $0.04(5)$ & $0.03(11)$ & $0.06(18)$ & $0.74(16)$ \\
$4.7-5.8$ & $0.00(8)$ & $0.06(10)$ & $0.24(8)$ & $0.75(7)$ & $0.14(11)$ & $0.02(2)$ & $0.01(5)$ & $0.03(10)$ & $0.54(12)$ \\
$3.3-4.7$ & $0.01(30)$ & $0.14(21)$ & $0.64(23)$ & $1.23(12)$ & $0.27(21)$ & $0.04(5)$ & $0.03(13)$ & $0.06(19)$ & $0.90(20)$ \\
$2.1-3.3$ & $0.01(22)$ & $0.07(10)$ & $0.56(20)$ & $0.87(9)$ & $0.14(11)$ & $0.04(5)$ & $0.02(9)$ & $0.04(13)$ & $0.67(15)$ \\
$1.1-2.1$ & $0.00(0)$ & $0.01(2)$ & $0.35(12)$ & $1.02(10)$ & $0.03(3)$ & $0.07(9)$ & $0.04(14)$ & $0.03(10)$ & $0.48(11)$ \\
$0.7-1.1$ & $0.00(0)$ & $0.00(0)$ & $0.12(4)$ & $1.23(12)$ & $0.01(0)$ & $0.25(32)$ & $0.05(17)$ & $0.01(3)$ & $0.11(2)$ \\
$0.4-0.7$ & $0.00(0)$ & $0.00(0)$ & $0.08(3)$ & $0.87(9)$ & $0.00(0)$ & $0.17(22)$ & $0.03(10)$ & $0.01(2)$ & $0.09(2)$ \\
$<0.4$ & $0.00(0)$ & $0.00(0)$ & $0.09(3)$ & $0.57(6)$ & $0.00(0)$ & $0.10(13)$ & $0.01(5)$ & $0.00(1)$ & $0.05(1)$ \\
\hline
\end{tabular}

a Number in parenthesis is the mass percentage in each stage (\%).

$\mathrm{SO}_{4}^{2-}$ and $\mathrm{NH}_{4}^{+}$and in coarse particles for $\mathrm{NO}_{3}^{-}, \mathrm{SO}_{4}^{2-}$ and $\mathrm{Ca}^{2+}$, respectively, based on their equivalent ratios. It can be seen that equivalent ratio of $\left[\mathrm{NH}_{4}^{+}\right]$to $\left[\mathrm{NO}_{3}^{-}+\mathrm{HSO}_{4}^{-}\right]$ is very close to unity with a high correlation efficient for fine particles at the site of Mt. Hua $\left(r^{2}=0.97, p=0.01\right.$, Fig. 11a), indicating that $\mathrm{NH}_{4}^{+}$exits in the forms of $\mathrm{NH}_{4} \mathrm{NO}_{3}$ and $\mathrm{NH}_{4} \mathrm{HSO}_{4}$. For the fine particles at the site of Mt. Tai, equivalent ratio of $\left[\mathrm{NH}_{4}^{+}\right]$to $\left[\mathrm{NO}_{3}^{-}+\mathrm{HSO}_{4}^{-}\right]$is lower than that of $\left[\mathrm{NH}_{4}^{+}\right]$to $\left[\mathrm{NO}_{3}^{-}+\mathrm{SO}_{4}^{2-}\right]$ (Fig. 11a and b), suggesting that most of $\mathrm{NH}_{4}^{+}$exits in the forms of $\mathrm{NH}_{4} \mathrm{NO}_{3}$ and $\left(\mathrm{NH}_{4}\right)_{2} \mathrm{SO}_{4}$ with certain amount of $\mathrm{NH}_{4} \mathrm{HSO}_{4}$. Such a difference in the chemical forms of $\mathrm{NH}_{4}^{+}$is attributed to the high level of $\mathrm{NH}_{3}$ in the Mt. Tai atmosphere, rendering more neu- tralizing matter for sulfate. During the non-dust period $\mathrm{Ca}^{2+}$ in the coarse size range $(>2.1 \mu \mathrm{m})$ showed a stronger correlation with $\mathrm{NO}_{3}^{-}$at Mt. Hua $\left(r^{2}=0.41, p=0.01\right.$, Fig. 12a) and Mt. Tai $\left(r^{2}=0.60, p=0.01\right.$, Fig. 12d) than with $\mathrm{SO}_{4}^{2-}$ (Fig. $12 \mathrm{~b}$ and e) and $\left[\mathrm{NO}_{3}^{-}+\mathrm{SO}_{4}^{2-}\right]$ (Fig. $12 \mathrm{c}$ and f), indicating that more $\mathrm{Ca}^{2+}$ exists as $\mathrm{Ca}\left(\mathrm{NO}_{3}\right)_{2}$ rather than $\mathrm{CaSO}_{4}$, especially in the Mt. Tai air (Fig. 12b-f). For the dust samples, $\mathrm{Ca}^{2+}$ displayed a stronger correlation with $\mathrm{SO}_{4}^{2-}$ and a weaker correlation with $\mathrm{NO}_{3}^{-}$(Fig. $12 \mathrm{~g}$ and h), suggesting that most of $\mathrm{Ca}^{2+}$ exists in the form of $\mathrm{CaSO}_{4}$ with certain amount of $\mathrm{Ca}\left(\mathrm{NO}_{3}\right)_{2}$. When nitrate is combined, the linear regression could further be improved $\left(\left[\mathrm{Ca}^{2+}\right]\right.$ versus $\left[\mathrm{NO}_{3}^{-}+\mathrm{SO}_{4}^{2-}\right], r^{2}=0.85, p=0.01$, Fig. $\left.12 \mathrm{i}\right)$, may imply 

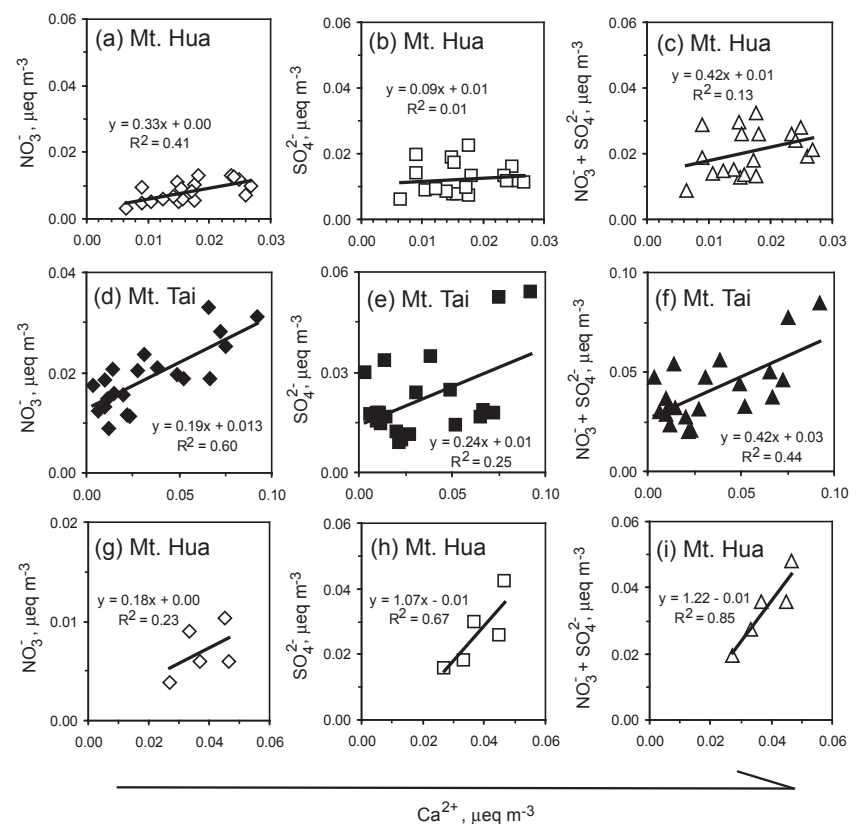

Fig. 12. Equivalent ratios of calcium to nitrate, sulfate and the sum of nitrate and sulfate in particles with a diameter larger than $2.1 \mu \mathrm{m}$ during (a-f) the non-dust storm and (g-i) dust storm periods.

an internal mixing state of $\mathrm{CaSO}_{4}$ with $\mathrm{Ca}\left(\mathrm{NO}_{3}\right)_{2}$ during the dust storm period. Such results are in agreement with the 1996 to 2008 record from Mauna Loa Observatory in Hawaii, showing that $19 \%$ of $\mathrm{CaCO}_{3}$ in Asian dust has reacted to form $\mathrm{CaSO}_{4}$ and $7 \%$ of the $\mathrm{CaCO}_{3}$ has reacted to form $\mathrm{Ca}\left(\mathrm{NO}_{3}\right)_{2}$ (McNaughton et al., 2009) $\mathrm{pH}$ values of the water-extracts showed that compared with those in the nondust period particle acidity during the event decreased significantly even for the particles with a diameter less than $0.4 \mu \mathrm{m}$ (Fig. 13a). During the non-event period particles with the strongest acidity are in the size of $0.7-1.1 \mu \mathrm{m}$ at Mt. Hua while those at Mt. Tai are in the size range of 1.1-2.1 $\mu \mathrm{m}$ (Fig. 13a and b).

\section{Summary and conclusions}

Atmospheric aerosols were simultaneously collected during the spring of 2009 at Mt. Hua and Mt. Tai in central and east coastal China, during which an intensive dust storm event occurred on 24 April. TSP and $\mathrm{PM}_{10}$ at Mt. Tai were two times higher than those at Mt. Hua in both the event and non-event periods. Concentrations of $\mathrm{SO}_{4}^{2-}$ and $\mathrm{Na}^{+}$in $\mathrm{PM}_{10}$ during the non-dust storm period at Mt. Tai were comparable to those at Mt. Hua, but EC, OC and other ions at Mt. Tai were 2-10 times higher than those at Mt. Hua especially for $\mathrm{Cl}^{-}$, $\mathrm{NO}_{3}^{-}, \mathrm{NH}_{4}^{+}$, and $\mathrm{K}^{+}$, suggesting more serious air pollution in the NCP region. During the non-dust storm period $\mathrm{NO}_{3}^{-}$was the dominant ion at Mt. Tai, followed by $\mathrm{SO}_{4}^{-}, \mathrm{NH}_{4}^{+}$, and $\mathrm{Ca}^{2+}$, in contrast to those at Mt. Hua, where $\mathrm{SO}_{4}^{-}$was the

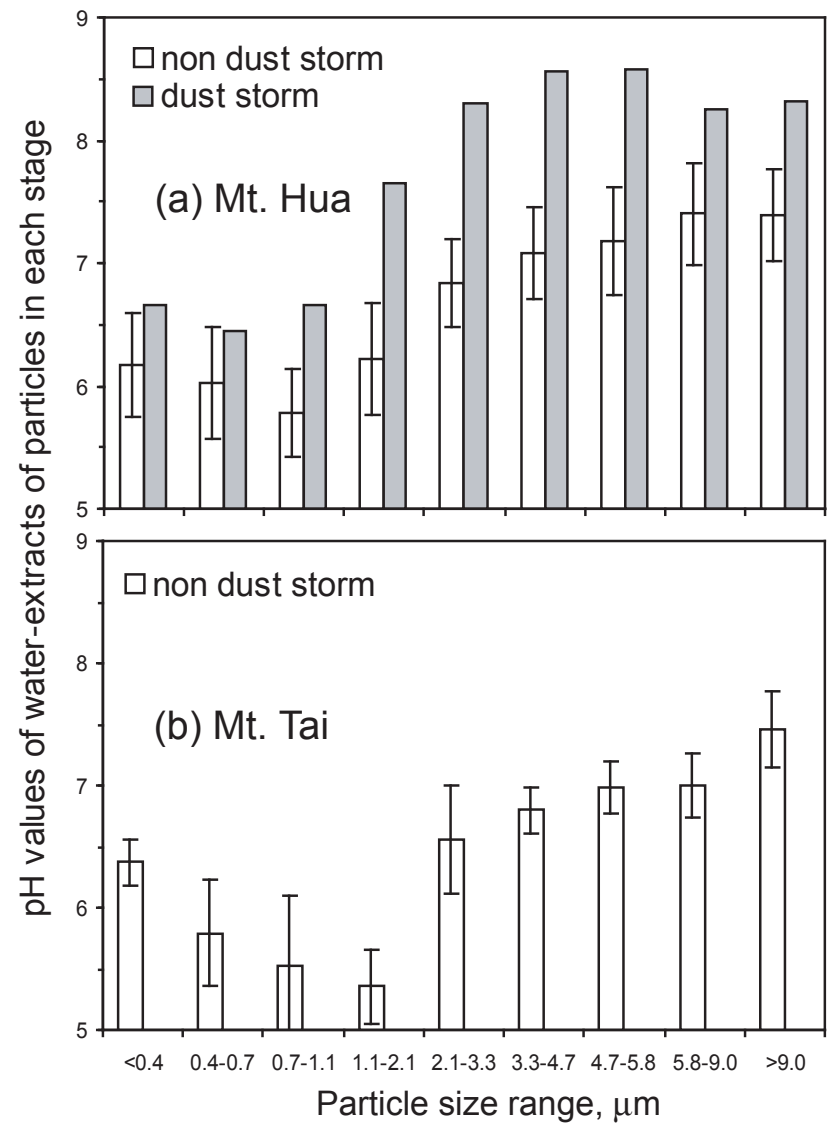

Fig. 13. Acidity of water-extracts of particles in each stage at (a) Mt. Hua and (b) Mt. Tai during the non-dust storm and dust storm periods.

highest, followed by $\mathrm{NO}_{3}^{-}, \mathrm{NH}_{4}^{+}$, and $\mathrm{Ca}^{2+}$. The exceeding of $\mathrm{NO}_{3}^{-}$over $\mathrm{SO}_{4}^{2-}$ at Mt. Tai indicates the changes in chemical composition of the atmosphere over East Asia due to the increasing nitrogen oxides caused by vehicle exhausts and industrial emissions. SOC/POC and SOC/EC ratios demonstrate that aerosol at Mt. Tai is more oxidized than that at Mt. Hua owing to high levels of precursors and oxidants in east coastal China. At both sites air masses transported from the south region contained higher levels of $\mathrm{SO}_{4}^{2-}$ and $\mathrm{NH}_{4}^{+}$compared to those transported from the north region, although $\mathrm{EC}$ and $\mathrm{OC}$ in the two directions were similar.

During the DSII period, concentrations of particles, OC, $\mathrm{Na}^{+}, \mathrm{K}^{+}, \mathrm{Mg}^{2+}$ and $\mathrm{Ca}^{2+}$ in the two mountain atmospheres increased by a factor of $1-9$, while $\mathrm{EC}, \mathrm{NO}_{3}^{-}$and $\mathrm{NH}_{4}^{+}$decreased by $20-80 \%$. However, there was no significant difference for $\mathrm{SO}_{4}^{2-}$ at both sites in either the dust storm or the non-dust storm periods, most likely due to a homogeneous spatial distribution of free tropospheric $\mathrm{SO}_{2}$.

During the non-event period $\mathrm{K}^{+}, \mathrm{Cl}^{-}$and $\mathrm{NO}_{3}^{-}$showed a significant difference in size distribution between the two mountains. $\mathrm{K}^{+}$at both sites was dominated in fine mode, but the coarse mode of $\mathrm{K}^{+}$was much more pronounced at 
Mt. Tai than at Mt. Hua. $\mathrm{Cl}^{-}$at Mt. Tai showed a similar patter to $\mathrm{K}^{+}$, while $\mathrm{Cl}^{-}$at Mt. Hua was largely present in coarse mode, because $\mathrm{Cl}^{-}$at Mt. Hua is largely derived from dust or dried lakes in north and northwest China while $\mathrm{K}^{+}$and $\mathrm{Cl}^{-}$ at Mt. Tai are mostly originated from biomass burning. Compared to that in Mt. Tai nitrate in Mt. Hua during the nonevent period was more enriched in coarse particles. When the dust storm was present, particles and all ions significantly shifted toward coarse particles, except for $\mathrm{NH}_{4}^{+}$, with a diminished and even disappeared peak in the fine mode. Equivalent ratios indicate that during the whole campaign ammonium exists largely as $\mathrm{NH}_{4} \mathrm{NO}_{3}$ and $\mathrm{NH}_{4} \mathrm{HSO}_{4}$ at Mt. Hua and $\mathrm{NH}_{4} \mathrm{NO}_{3}$ and $\left(\mathrm{NH}_{4}\right)_{2} \mathrm{SO}_{4}$ at Mt. Tai, while calcium ion exists mostly as $\mathrm{Ca}\left(\mathrm{NO}_{3}\right)_{2}$ during the non-event and as $\mathrm{CaSO}_{4}$ during the event.

Acknowledgements. This work was financially supported by National Nature Science Foundation of China (No. 40873083) and the Knowledge Innovation Program of Chinese Academy of Science (No. KZCX2-YW-148).

Edited by: S. C. Liu

\section{References}

Akimoto, H.: Global air quality and pollution, Science, 302, 17161719, 2003.

Aldhous, P.: China's burning ambition, Nature, 435, 1152-1154, 2005.

Andreae, M. O., Andreae, T. W., Annegarn, H., Beer, J., Cachier, H., leCanut, P., Elbert, W., Maenhaut, W., Salma, I., Wienhold, F. G., and Zenker, T.: Airborne studies of aerosol emissions from savanna fires in southern Africa: 2. Aerosol chemical composition, J. Geophys. Res., 103(D24), doi:10.1029/98JD00107, 32119-32128, 1998.

Arimoto, R., Zhang, X. Y., Huebert, B. J., Kang, C. H., Savoie, D. L., Prospero, J. M., Sage, S. K., Schloesslin, C. A., Khaing, H. M., and Oh, S. N.: Chemical composition of atmospheric aerosols from Zhenbeitai, China, and Gosan, South Korea, during ACE-Asia, J. Geophys. Res.-Atmos., 109 D19S04, doi:10.1029/2003JD004323, 2004.

Arimoto, R., Kim, Y. J., Kim, Y. P., Quinn, P. K., Bates, T. S., Anderson, T. L., Gong, S., Uno, I., Chin, M., Huebert, B. J., Clarke, A. D., Shinozuka, Y., Weber, R. J., Anderson, J. R., Guazzotti, S. A., Sullivan, R. C., Sodeman, D. A., Prather, K. A., and Sokolik, I. N.: Characterization of Asian Dust during ACE-Asia, Global Planet. Change, 52, 23-56, 2006.

Cao, J. J., Chow, J. C., Watson, J. G., Wu, F., Han, Y. M., Jin, Z. D., Shen, Z. X., and An, Z. S.: Size - differentiated source profiles for fugitive dust in the Chinese Loess Plateau, Atmos. Environ., 42, 2261-2275, 2008.

Castro, L. M., Pio, C. A., Harrison, R. M., and Smith, D. J. T.: Carbonaceous aerosol in urban and rural European atmospheres: estimation of secondary organic carbon concentrations, Atmos. Environ., 33, 2771-2781, 1999.

Chiu, H. F., Tiao, M. M., Ho, S. C., Kuo, H. W., Wu, T. N., and Yang, C. Y.: Effects of Asian dust storm events on hospital ad- missions for chronic obstructive pulmonary disease in Taipei, Taiwan, Inh. Toxicol., 20, 777-781, 2008.

Chow, J. C., Watson, J. G., Chen, L.-W. A., Arnott, W. P., Moosmuller, H., and Fung, K. K.: Equivalence of elemental carbon by thermal/optical reflectance and transmittance with different temperature protocols, Environ. Sci. Tech., 38, 4414-4422, 2004.

Chow, J. C., Watson, J. G., Chen, L.-W. A., Chang, M. C. O., Robinson, N. F., Trimble, D., and Kohl, S.: The IMPROVE temperature protocol for thermal/optical carbon analysis: maintaining consistency with a long-term database, J. Air Waste Manage., 57, 1014-1023, 2007.

Chu, S. H.: Stable estimate of primary OC/EC ratios in the EC tracer method, Atmos. Environ., 39, 1383-1392, 2005.

Decesari, S., Facchini, M. C., Fuzzi, S., McFiggans, G. B., Coe, H., and Bower, K. N.: The water-soluble organic component of sizesegregated aerosol, cloud water and wet depositions from Jeju Island during ACE-Asia, Atmos. Environ., 39, 211-222, 2005.

Engling, G. and Gelencser, A.: Atmospheric brown clouds: From local air pollution to climate change, Elements, 6, 223-228, 2010.

Finlayson-Pitts, B. J., Ezell, M. J., and Pitts Jr, J. N.: Formation of chemically active chlorine compounds by reactions of atmospheric $\mathrm{NaCl}$ particles with gaseous $\mathrm{N}_{2} \mathrm{O}_{5}$ and $\mathrm{ClONO}_{2}$, Nature, 337, 241-244, 1989.

Fu, J. S., Jang, C. J., Streets, D. G., Li, Z., Kwok, R., Park, R., and Han, Z.: MICS-Asia II: Modeling gaseous pollutants and evaluating an advanced modeling system over East Asia, Atmos. Environ., 42, 3571-3583, 2008.

Gaffney, J. S. and Marley, N. A.: The impacts of combustion emissions on air quality and climate - From coal to biofuels and beyond, Atmos. Environ., 43, 23-36, 2009.

Gao, J., Wang, T., Ding, A. J., and Liu, C. B.: Observational study of ozone and carbon monoxide at the summit of mount Tai (1534 m a.s.1.) in central-eastern China, Atmos. Environ., 39, 4779-4791, 2005.

Geng, H., Park, Y., Hwang, H., Kang, S., and Ro, C.-U.: Elevated nitrogen-containing particles observed in Asian dust aerosol samples collected at the marine boundary layer of the Bohai Sea and the Yellow Sea, Atmos. Chem. Phys., 9, 6933-6947, doi:10.5194/acp-9-6933-2009, 2009.

Hand, J. L., Malm, W. C., Laskin, A., Day, D., Lee, T., Wang, C., Carrico, C., Carrillo, J., Cowin, J. P., Collett, J., and Iedema, M. J.: Optical, physical, and chemical properties of tar balls observed during the Yosemite Aerosol Characterization Study, J. Geophys. Res.-Atmos., 110, D21210, doi:10.1029/2004JD005728, 2005.

Hatakeyama, S., Takami, A., Wang, W., and Tang, D.: Aerial observation of air pollutants and aerosols over Bo Hai, China, Atmos. Environ., 39, 5893-5898, 2005.

Heald, C. L., Jacob, D. J., Park, R. J., Alexander, B., Fairlie, T. D., Yantosca, R. M., and Chu, D. A.: Transpacific transport of Asian anthropogenic aerosols and its impact on surface air quality in the United States, J. Geophys. Res., 111, D14310, doi:10.1029/2005JD006847, 2006.

Hong, Y. C., Pan, X. C., Kim, S. Y., Park, K., Park, E. J., Jin, X. B., Yi, S. M., Kim, Y. H., Park, C. H., Song, S., and Kim, H.: Asian dust storm and pulmonary function of school children in Seoul, Sci. Total Environ., 408, 754-759, 2010.

Huang, K., Zhuang, G. S., Li, J. A., Wang, Q. Z., Sun, Y. L., Lin, 
Y. F., and Fu, J. S.: Mixing of Asian dust with pollution aerosol and the transformation of aerosol components during the dust storm over China in spring 2007, J. Geophys. Res.-Atmos., 115, D00K13, doi:10.1029/2009JD013145, 2010a.

Huang, K., Zhuang, G. S., Lin, Y. F., Li, J. A., Sun, Y. L., Zhang, W. J., and Fu, J. S.: Relation between optical and chemical properties of dust aerosol over Beijing, China, J. Geophys. Res.Atmos., 115, D00K16, doi:10.1029/2009JD013212, 2010b.

Huebert, B. J., Bates, T., Russell, P. B., Shi, G. Y., Kim, Y. J., Kawamura, K., Carmichael, G., and Nakajima, T.: An overview of ACE-Asia: Strategies for quantifying the relationships between Asian aerosols and their climatic impacts, J. Geophys. Res.-Atmos., 108, 8663, doi:10.1029/2003JD003550, 2003.

Ikegami, M., Okada, K., Zaizen, Y., Makino, Y., Jensen, J. B., Gras, J. L., and Harjanto, H.: Very high weight ratios of S/K in individual haze particles over Kalimantan during the 1997 Indonesian forest fires, Atmos. Environ., 35, 4237-4243, 2001.

IPCC: The Fourth Assessment Report of the Intergovernmental Panel on Climate Change, Cambridge University Press, New York, USA, 2007.

Kanayama, S., Yabuki, S., Yanagisawa, F., and Motoyama, R.: The chemical and strontium isotope composition of atmospheric aerosols over Japan: the contribution of long-range-transported Asian dust (Kosa), Atmos. Environ., 36, 5159-5175, 2002.

Leaitch, W. R., Macdonald, A. M., Anlauf, K. G., Liu, P. S. K., Toom-Sauntry, D., Li, S.-M., Liggio, J., Hayden, K., Wasey, M. A., Russell, L. M., Takahama, S., Liu, S., van Donkelaar, A., Duck, T., Martin, R. V., Zhang, Q., Sun, Y., McKendry, I., Shantz, N. C., and Cubison, M.: Evidence for Asian dust effects from aerosol plume measurements during INTEXB 2006 near Whistler, BC, Atmos. Chem. Phys., 9, 3523-3546, doi:10.5194/acp-9-3523-2009, 2009.

Li, J., Pósfai, M., Hobbs, P. V., and Buseck, P. R.: Individual aerosol particles from biomass burning in southern Africa: 2, Compositions and aging of inorganic particles, J. Geophys. Res., 108(D13), 8484, doi:10.1029/2002JD002310, 2003.

Li, J., Wang, G., Zhou, B., Cheng, C., Cao, J., Shen, Z., and An, Z.: Chemical composition and size distribution of wintertime aerosols in the atmosphere of Mt. Hua in central China, Atmos. Environ., 45, 1251-1258, 2011.

Liu, J. G. and Diamond, J.: China's environment in a globalizing world: How China and the rest of the world affect each other, Nature, 435, 1179-1186, 2005.

McNaughton, C. S., Clarke, A. D., Kapustin, V., Shinozuka, Y., Howell, S. G., Anderson, B. E., Winstead, E., Dibb, J., Scheuer, E., Cohen, R. C., Wooldridge, P., Perring, A., Huey, L. G., Kim, S., Jimenez, J. L., Dunlea, E. J., DeCarlo, P. F., Wennberg, P. O., Crounse, J. D., Weinheimer, A. J., and Flocke, F.: Observations of heterogeneous reactions between Asian pollution and mineral dust over the Eastern North Pacific during INTEX-B, Atmos. Chem. Phys., 9, 8283-8308, doi:10.5194/acp-9-8283-2009, 2009.

Mori, I., Nishikawa, M., Tanimura, T., and Quan, H.: Change in size distribution and chemical composition of kosa (Asian dust) aerosol during long-range transport, Atmos. Environ., 37, 42534263, 2003.

Parrington, J. R., Zoller, W. H., and Aras, N. K.: Asian dust: Seasonal transport to the Hawaiian Islands., Science, 220, 195-197, 1983.
Pathak, R. K., Wu, W. S., and Wang, T.: Summertime PM2.5 ionic species in four major cities of China: nitrate formation in an ammonia-deficient atmosphere, Atmos. Chem. Phys., 9, 17111722, doi:10.5194/acp-9-1711-2009, 2009.

Pathak, R. K., Wang, T., and Wu, W.S.: Nighttime enhancement of PM2.5 nitrate in ammonia-poor atmospheric conditions in Beijing and Shanghai: Plausible contributions of heterogeneous hydrolysis of $\mathrm{N}_{2} \mathrm{O}_{5}$ and $\mathrm{HNO}_{3}$ partitioning, Atmos. Environ., 45, 1183-1191, doi.:10.1026/j.atmosenv.2010.09.003, 2010.

Pósfai, M., Simonics, R., Li, J., Hobbs, P. V., and Buseck, P. R.: Individual aerosol particles from biomass burning in southern Africa:1. Compositions and size distributions of carbonaceous particles, J. Geophys. Res., 103(D13), 8483, doi:10.1029/2002JD002291, 2003.

Ramana, M. V., Ramanathan, V., Feng, Y., Yoon, S.-C., Kim, S.W., Carmichael, G. R., and Schauer, J. J.: Warming influenced by the ratio of black carbon to sulphate and the black-carbon source, Nat. Geosci., 3, 542-545, 2010.

Richter, A., Burrows, J., Nub, H., Granier, C., and Niemeier, U.: Increase in tropospheric nitrogen dioxide over China observed from space, Nature, 437, 129-132, 2005.

Rosenfeld, D., Dai, J., Yu, X., Yao, Z., Xu, X., Yang, X., and Du, C.: Inverse relations between amounts of air pollution and orographic precipitation, Science, 315, 1396-1398, 2007.

Seinfeld, J. H. and Pandis, S. N.: Atmospheric Chemistry and Physics, John Wiley \& Sons, New York, 1998.

Seinfeld, J. H., Carmichael, G. R., Arimoto, R., Conant, W. C., Brechtel, F. J., Bates, T. A., Cahill, T. A., Clarke, A. D., Doherty, S. J., Flatau, P. J., Huebert, B. J., Kim, J., Markowicz, K. M., Quinn, P. K., Russell, L. M., Russell, P. B., Shimizu, A., Shinozuka, Y., Song, C. H., Tang, Y. H., Uno, I., Vogelmann, A. M., Weber, R. J., Woo, J. H., and Zhang, X. Y: ACE-Asia: Regional climatic and atmospheric chemical effects of Asian dust and pollution, B. Am. Meteorol. Soc., 85, 367-380, doi:10.1175/BAMS85-3-367, 2004.

Singh, H. B., Brimblecombe, P., and Veenstra, F.: Atmospheric Environment Special Issue Fifty Years of Endeavour, Atmos. Environ., 43, 1 pp., doi:10.1016/j.atmosenv.2008.09.017, 2009.

Song, C. H. and Carmichael, G. R.: The aging process of naturally emitted aerosol (sea-salt and mineral aerosol) during long range transport, Atmos. Environ., 33, 2203-2218, 1999.

Streets, D. G. and Waldhoff, S. T.: Present and future emissions of air pollutants in China:: $\mathrm{SO}_{2}, \mathrm{NO}_{\mathrm{x}}$, and $\mathrm{CO}$, Atmos. Environ., 34, 363-374, 2000.

Streets, D. G., Bond, T. C., Carmichael, G. R., Fernandes, S. D., Fu, Q., He, D., Klimont, Z., Nelson, S. M., Tsai, N. Y., Wang, M. Q., Woo, J.-H., and Yarber, K. F.: An inventory of gaseous and primary aerosol emission in Asia in the year 2000, J. Geophys. Res., 108(D21), 8809, doi:10.1029/2002JD003093, 2003.

Sullivan, R. C., Guazzotti, S. A., Sodeman, D. A., and Prather, K. A.: Direct observations of the atmospheric processing of Asian mineral dust, Atmos. Chem. Phys., 7, 1213-1236, doi:10.5194/acp-7-1213-2007, 2007.

Sullivan, R. C., Moore, M. J. K., Petters, M. D., Kreidenweis, S. M., Roberts, G. C., and Prather, K. A.: Effect of chemical mixing state on the hygroscopicity and cloud nucleation properties of calcium mineral dust particles, Atmos. Chem. Phys., 9, 33033316, doi:10.5194/acp-9-3303-2009, 2009.

Sun, Y. L., Zhuang, G. S., Ying, W., Han, L. H., Guo, J. H., Mo, D., 
Zhang, W. J., Wang, Z. F., and Hao, Z. P.: The air-borne particulate pollution in Beijing - concentration, composition, distribution and sources, Atmos. Environ., 38, 5991-6004, 2004.

Sun, Y., Zhuang, G., Huang, K., Li, J., Wang, Q., Wang, Y., Lin, Y., Fu, J.S., Zhang, W., Tang, A., and Zhao, X.: Asian dust over northern China and its impact on the downstream aerosol chemistry in 2004, J. Geophys. Res.-Atmos., 115, D00KO9, doi:10.1029/2009JD012757, 2010.

Takiguchi, Y., Takami, A., Sadanaga, Y., Lun, X. X., Shimizu, A., Matsui, I., Sugimoto, N., Wang, W., Bandow, H., and Hatakeyama, S.: Transport and transformation of total reactive nitrogen over the East China Sea, J. Geophys. Res.-Atmos., 113, D10306, doi:10.1029/2007JD009462, 2008.

Tobo, Y., Zhang, D., Matsuki, A., and Iwasaka, Y.: Asian dust particles converted into aqueous droplets under remote marine atmospheric conditions, P. Natl. Acad. Sci. USA, 107, 17905-17910, 2010 .

Trochkine, D., Iwasaka, Y., Matsuki, A., Yamada, M., Kim, Y. S., Nagatani, T., Zhang, D., Shi, G. Y., and Shen, Z.: Mineral aerosol particles collected in Dunhuang, China, and their comparison with chemically modified particles collected over Japan, J. Geophys. Res.-Atmos., 108, 8642, doi:10.1029/2002JD003268, 2003.

Uno, I., Eguchi, K., Yumimoto, K., Takemura, T., Shimizu, A., Uematsu, M., Liu, Z. Y., Wang, Z. F., Hara, Y., and Sugimoto, N.: Asian dust transported one full circuit around the globe, Nat. Geosci., 2, 557-560, 2009.

VanCuren, R. A. and Cahill, T. A.: Asian aerosols in North America: Frequency and concentration of fine dust, J. Geophys. Res., 107, 484, doi:10.1029/2002JD002204, 2002.

van Donkelaar, A., Martin, R. V., Brauer, M., Kahn, R., Levy, R., Verduzco, C., and Villeneuve, P. J.: Global estimates of ambient fine particulate matter concentrations from satellite-based aerosol optical depth: development and application, Environ. Health Persp., 118, 8347-855, 2010.

Wang, G., Huang, L., Gao, S., Gao, S., and Wang, L.: Characterization of water-soluble species of $\mathrm{PM}_{10}$ and $\mathrm{PM}_{2.5}$ aerosols in urban area in Nanjing, China, Atmos. Environ., 36, 1299-1307, 2002a.

Wang, G. H., Niu, S. L., Liu, C. and Wang, L. S.: Identification of dicarboxylic acids and aldehydes of $\mathrm{PM}_{10}$ and $\mathrm{PM}_{2.5}$ aerosols in Nanjing, China, Atmos. Environ., 36, 1941-1950, 2002 b.

Wang, G., Wang, H., Yu, Y., Gao, S., Feng, J., Gao, S., and Wang, L.: Chemical characterization of water-soluble components of $\mathrm{PM}_{10}$ and $\mathrm{PM}_{2.5}$ atmospheric aerosols in five locations of Nanjing, China, Atmos. Environ., 37, 2893-2902, 2003.

Wang, G., Kawamura, K., and Lee, M.: Comparison of organic compositions in dust storm and normal aerosol samples collected at Gosan, Jeju Island, during spring 2005, Atmos. Environ., 43, 219-227, 2009a.

Wang, G., Kawamura, K., Umemoto, N., Xie, M., Hu, S., and Wang, Z.: Water-soluble organic compounds in PM2.5 and sizesegregated aerosols over Mt. Tai in North China Plain, J. Geophys. Res.-Atmos., 114, D19208, dio.10.1029/2008JD011390, 2009 b.
Wang, G., Kawamura, K., Xie, M., Hu, S., Gao, S., Cao, J., An, Z., and Wang, Z.: Size-distributions of n-alkanes, PAHs and hopanes and their sources in the urban, mountain and marine atmospheres over East Asia, Atmos. Chem. Phys., 9, 8869-8882, doi:10.5194/acp-9-8869-2009, 2009c.

Wang, G., Xie, M., Hu, S., Gao, S., Tachibana, E., and Kawamura, K.: Dicarboxylic acids, metals and isotopic compositions of $\mathrm{C}$ and $\mathrm{N}$ in atmospheric aerosols from inland China: implications for dust and coal burning emission and secondary aerosol formation, Atmos. Chem. Phys., 10, 6087-6096, doi:10.5194/acp-106087-2010, 2010.

Wang, G., Zhou, B., Li, J., Chen, C., Cao, J., Shen, Z., and An, Z.: Seasonal variations of EC,OC and ions of airborne particles in Xi' an central China, in preperation, 2011.

Wang, G. H., Kawamura, K., Zhao, X., Li, Q. G., Dai, Z. X., and Niu, H. Y.: Identification, abundance and seasonal variation of anthropogenic organic aerosols from a mega-city in China, Atmos. Environ., 41, 407-416, 2007.

Wang, Y., Zhuang, G., Sun, Y., and An, Z.: The variation of characteristics and formation mechanisms of aerosols in dust, haze, and clear days in Beijing, Atmos. Environ., 40, 6579-6591, 2006 a.

Wang, Y., Zhuang, G., Zhang, X., Huang, K., Xu, C., Tang, A., Chen, J., and An, Z.: The ion chemistry, seasonal cycle, and sources of $\mathrm{PM}_{2.5}$ and TSP aerosol in Shanghai, Atmos. Environ., 40, 2935-2952, $2006 \mathrm{~b}$.

Wilkening, K. E., Barrie, L. A., and Engle, M.: Trans-Pacific Air Pollution, Science, 290, 65-67, 2000.

Wittrock, F., Richter, A., Oetjen, H., Burrows, J. P., Kanakidou, M., Myriokefalitakis, S., Volkamer, R., Beirle, S., Platt, U., and Wagner, T.: Simultaneous global observations of glyoxal and formaldehyde from space, Geophys. Res. Lett., 33, L16804, doi:10.1029/2006GL026310, 2006.

Xie, M., Wang, G., Hu, S., Gao,S., Han, Q., Xu, Y., and Feng, $\mathrm{J}$.: Polar organic and inorganic markers in $\mathrm{PM}_{10}$ aerosols from an inland city of China - seasonal trends and sources, Sci. Total Environ., 408, 5452-5460, 2010.

Xue, L., Ding, A., Gao, J., Wang, T., Wang, W., Wang, X., Lei, H., Ji, D., and Qi, Y.: Aircraft measurements of the vertical distribution of sulfur dioxide and aerosol scattering coefficient in China, Atmos. Environ., 44, 278-282, 2010.

Yu, X.-Y., Cary, R. A., and Laulainen, N. S.: Primary and secondary organic carbon downwind of Mexico City, Atmos. Chem. Phys., 9, 6793-6814, doi:10.5194/acp-9-6793-2009, 2009.

Yuan, H., Zhuang, G. S., Li, J., and Wang, Z. F.: Mixing of mineral with pollution aerosols in dust season in Beijing: Revealed by source apportionment study, Atmos. Environ., 42, 2141-2157, 2008.

Zhang, D. Z., Zang, J. Y., Shi, G. Y., Iwasaka, Y., Matsuki, A., and Trochkine, D.: Mixture state of individual Asian dust particles at a coastal site of Qingdao, China, Atmos. Environ., 37, 38953901, 2003.

Zhang, X. Y., Zhuang, G. S., Yuan, H., Rahn, K. A., Wang, Z. F., and An, Z. S.: Aerosol Particles from Dried Salt-Lakes and Saline Soils Carried on Dust Storms over Beijing, Terr. Atmos. Oceanic Sci., 20, 619-628, 2009. 